$$
\begin{aligned}
& \text { Bird Observations } \\
& \text { Mear } \\
& \text { Chicago }
\end{aligned}
$$

Willen Drummond Farwell. 


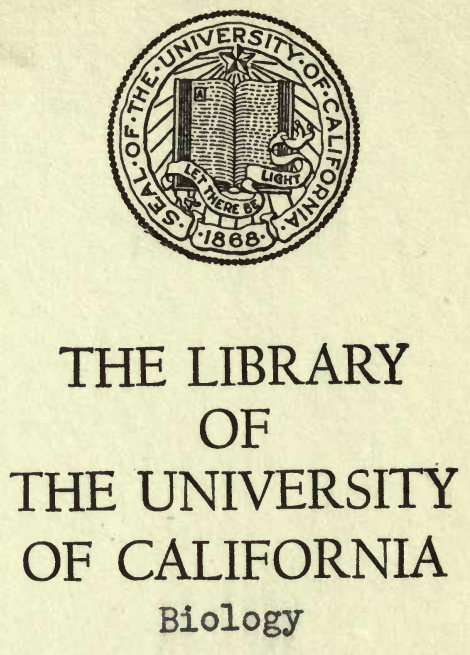

BEQUEST OF

Theodore S. Palmer 
T. S. Palmex Qel 25, 1919 



\section{BIRD OBSERVATIONS NEAR CHICAGO}





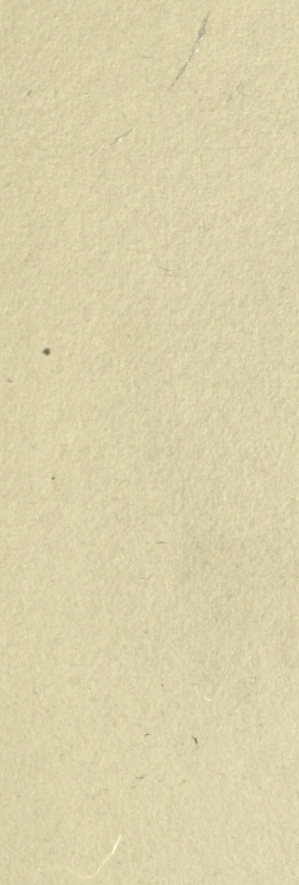




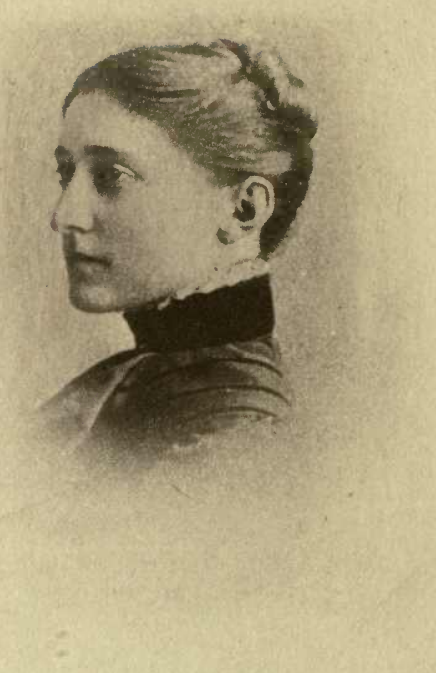




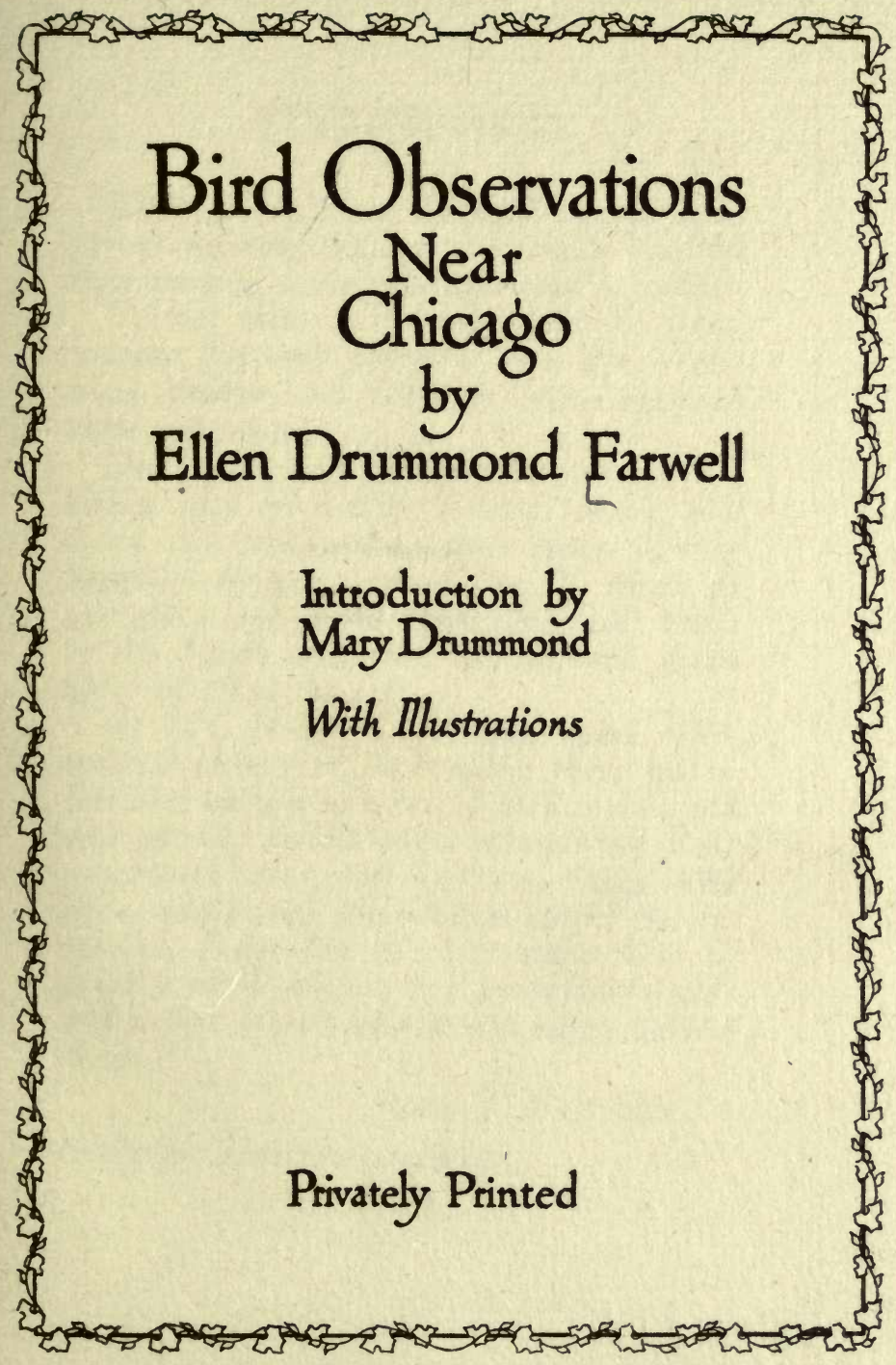




\section{Copyrighted 1919}

by

John V. Farwell 


\section{FOREWORD}

Ellen Drummond Farwell loved birds for many reasons, but especially because they seemed to her the spiritual in nature.

To her their songs expressed the spontaneous joy and gladness of a life, seemingly higher and freer in some respects than our own.

During the last years of her life, as her duties and pleasures became more and more restricted, she spent some of her happiest moments observing the birds on our place and in the neighborhood. Once in the South and once abroad she made notes of what she saw.

As $\mathrm{Mr}$. Henry Oldys and some other trained observers, in reading these notes, felt that quite a number of bird lovers, old and young, would enjoy comparing their notes with these, and that in so doing some little additional knowledge might be recorded, I decided at their suggestion to print a small edition for personal friends and a few others who might enjoy having them.

\section{JohN V. FARWELL.}

Ardleigh, January 20, I9I9.

$$
\text { [5] }
$$





\section{CONTENTS}

Page

Foreword ............. 5

Introduction $\ldots \ldots \ldots \ldots \ldots \ldots$ I I

Warblers Identified, Elmhurst and

Lake Forest ............ I7

List of Birds that We Have Found

Nesting in Ardleigh and Edgewood I9

List of Birds Observed at Augusta,

Ga. ................ 2 I

Number of Species Observed at One

Time ............... 23

General Observations ......... 25

Bird Observations in Europe...... I69

Notes Made from Collection of Birds

in Illinois Building at the World's

Fair ............... 185

Birds Observed at Savannah, Ga... I 89

Observations before July, I896, were made generally in Elmhurst, after that generally in Lake Forest.

$$
\text { [7] }
$$





\section{LIST OF ILLUSTRATIONS}

Portrait of Mrs. Farwell....Frontispiece opposite page

Spotted Sand Piper .......... I 7

Nest of Meadow Lark ......... 23

Ardleigh ................ 25

Young Chicadee ............ 40

Nest of Indigo Bunting. ........ 62

Great Horned Owl (captive) ..... 74

Young Phoebes ............. 77

Nashville Warbler ........... 142

Nest of Field Sparrow ......... I 88

The photographs from which these illustrations were made were taken by Henry Emerson Tuttle through whose courtesy they are used. 



\section{INTRODUCTION}

It is hoped that these "Bird Observations" by Ellen Drummond Farwell may be welcomed by bird students, because of the accuracy and extent of their observations and the possibility that they may supply some new data, particularly as to bird songs. By Mrs. Farwell's personal friends they will also be welcomed as bringing back to them the thought of one whose mental ability, true Christian loveliness and nobility of character created a personality always uplifting and strengthening in its influence.

Partly through the influence of Mrs. Sara A. Hubbard, to whom many can trace their first interest in birds, and partly, it sometimes seemed, because of a kinship between the birds, the least earthly of the animal creation,

"Whose habitations in the tree-tops even, Are half-way, houses on the road to Heaven,"

and her own deeply spiritual nature, she turned more and more to bird study with much interest and pleasure. Like most

$$
\text { [ I I ] }
$$




\section{Introduction}

bird students, she soon formed the habit of jotting down her experiences and the "observations" are the result-kept, it need hardly be said-with no thought of their being seen by any but her closest friends and fellow bird lovers.

For a number of years, in spite of long intervals of illness, these notes were kept, the last being entered not many days before her death.

It was a very curious fact that while the ordinary songs of the birds did not rouse her from her light morning sleep, an unusual note would waken her at once; that, in the spring before her death, when all she could see and hear of the birds was from her bed, a Hermit Thrush should sing his lovely song near her window seemed like a special benediction. His song is rarely heard in this latitude and her joy in it was great. Her hearing was very acute and she knew all the common and most of the uncommon notes of the birds of this region.

Mrs. Farwell was not only a bird student but a bird lover and this implied, with one like her, that, as much happiness came to her from the birds, so she must do for their happiness all in her power

$$
\text { [ } 12 \text { 2 }
$$




\section{Introduction}

and so it was that she was one of the chief organizers of the Illinois Audubon Society (April, 1897), and served, either as director or vice-president, till her death. Must we not feel that her chief wish, in the publication of these notes, would be that they might help, in their measure, the cause of bird protection which was so near her heart, and for which she worked so earnestly and well?

\section{Mary Drummond.}

Lake Forest, January 20, I9I9. 


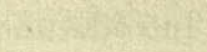




\section{BIRD OBSERVATIONS NEAR}

CHICAGO 




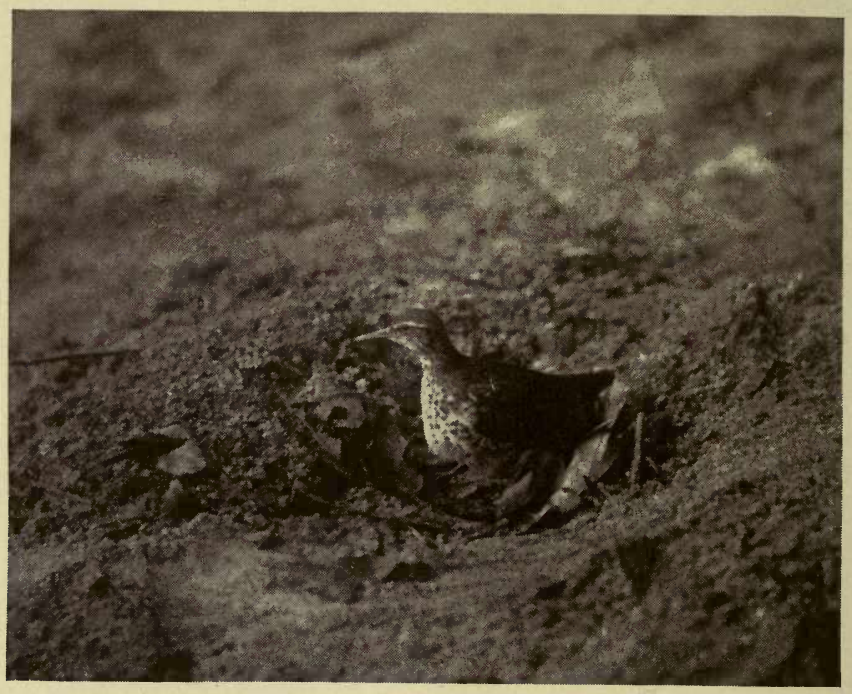

Spotted Sandpiper

Brooding Young * 


\section{BIRD OBSERVATIONS}

\section{WARBLERS IDENTIFIED}

Elmhurst and Lake Forest

BAY-BREASTED,

- BLACK AND WHITE,

BLACK-THROATED BLUE,

BLACK-THROATED GREEN,

BLACKBURNIAN,

BLACK-POLL,

CANADIAN,

CAPE MAY,

CERULEAN,

CHESTNUT-SIDED,

CONNECTICUT,

GOLDEN-WINGED,

MAGNOLIA,

MOURNING,

MYRTLE,

MARYLAND YELLOW-THROAT,

NASHVILLE,

ORANGE-CROWNED,

OVEN-BIRD,

PARULA,

[ 17 ] 


\section{Bird Observations}

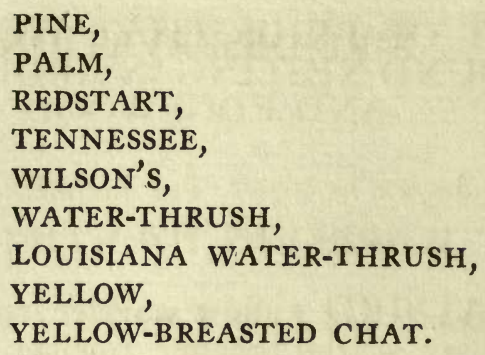

In Georgia.

YELLOW-THROATED, HOODED.

[ 18 ] 


\section{LIST OF BIRDS THAT WE HAVE FOUND NESTING IN ARDLEIGH AND EDGEWOOD}

List begun in 1907, but including former years also

CATBIRD, yellow warbler, robin, blue jay, scarlet tanager, towhee, redstart, red-eyed vireo, great crested flycatcher, phoebe, wood thrush, flicker, red-headed woodpecker, cedar bird, chimney swift, indigo bird, brown thrasher, song sparrow, house wren.

August 8, 190I. Saw first fall migrant, a young warbler, what species I could not decide.

May 2 and 3, 1902. After a warm day, and a shower the night of May Ist, I observed twenty-three new immigrants, fourteen of them warblers, in the two days. 


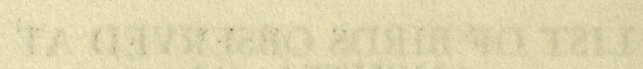

. 3 


\section{Bird Observations}

bler's in two hours in the morning. On this day I saw three Blackburnians, one bay-breasted, one black-throated blue, two chestnut sided and a parula in one tree. Warblers very abundant this year. blers.

May 15, 1894. Eleven species warMay 7,1895 . Eleven species warblers. 



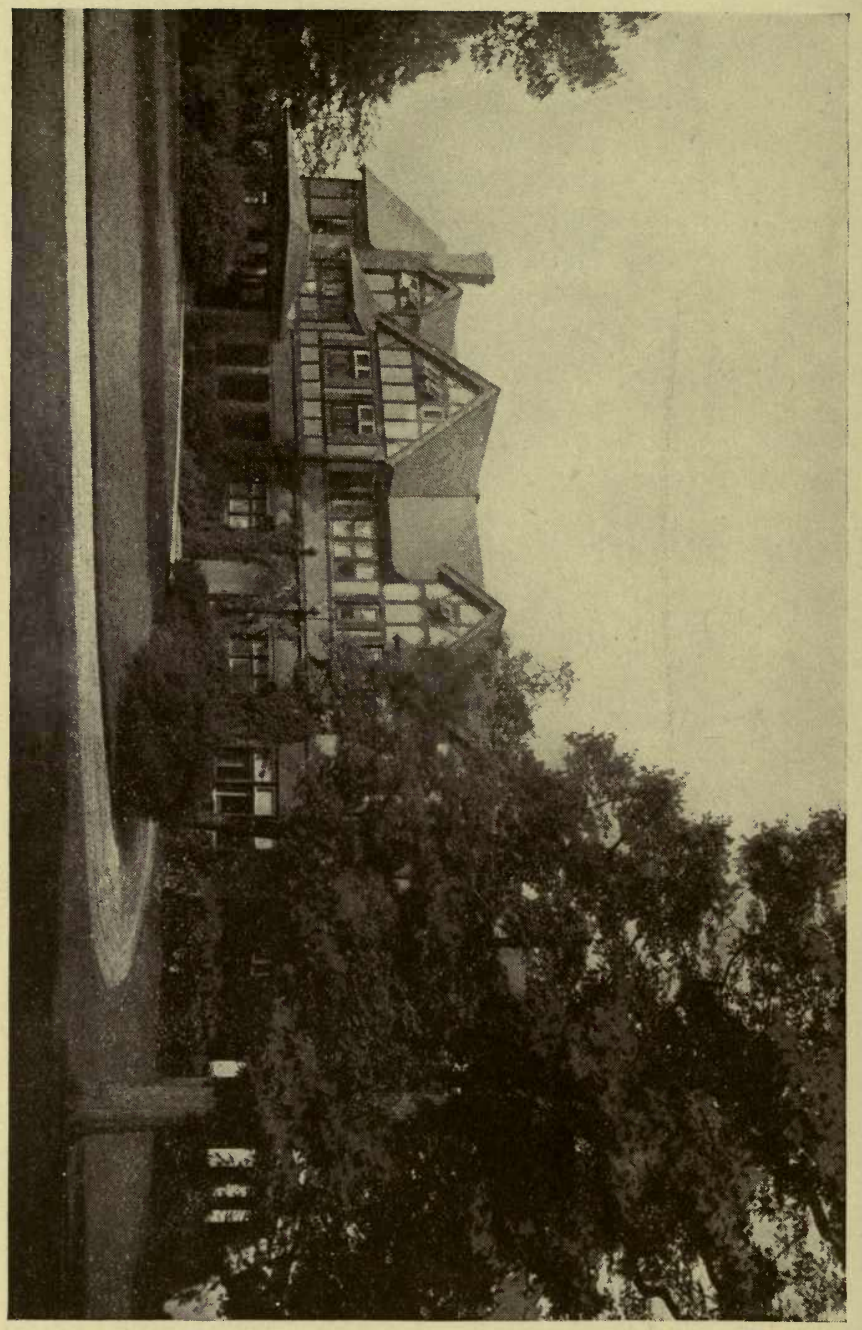




\section{GENERAL OBSERVATIONS}

\section{May I2, 1905, at Lake Forest, noted fifty-seven species}

B LUEBIRD, bobolink, indigo bird, catB bird, cowbird, crow, Acadian flycatcher, yellow-bellied flycatcher, chebec, phoebe, blue grey gnatcatcher, goldfinch, humming bird, jay, kingbird, ruby kinglet, nighthawk, Baltimore oriole, robin, sapsucker, red-headed woodpecker, house sparrow, song sparrow, vesper sparrow, white-throated sparrow, swift, tanager, brown thrasher, grey-checked thrush, wood thrush, olive-backed thrush, Wilson's thrush, towhee, red-eyed vireo, ${ }^{*}$ yellow throated-vireo. (Warblers), black-throated green, black-throated blue, black and white creeper, Blackburnian, Canadian, chestnut-sided, Cape May, magnolia, myrtle, Maryland yellow-throat, oven bird, orange-crowned, ${ }^{*}$ parula, palm, Tennessee, Wilson's, yellow, water thrush, redstart, house wren, whip-poor-will.

May ${ }^{1} 5$, 1906. Noted fifty-six species, Lake Forest. Catbird, house wren, brown

* Not absolutely certain.

[25] 


\section{Bird Observations}

thrasher, cowbird, red-wing, blackbird, grackle, Baltimore oriole, meadow lark, bobolink, robin, wood thrush, Wilson's thrush, bluebird, towhee, blue jay, crow, swift, martin, chickadee, mourning dove, kingbird, phoebe, pewee, great crested flycatcher, chebec, red-headed woodpecker, downy, sapsucker, flicker, chipping sparrow, field, vesper, song and house sparrow, indigo bird, rose-breasted grosbeak, goldfinch, tanager, red-eyed vireo, solitary vireo, yellow-throated vireo, coot, Virginia rail, Carolina rail, yellow, cerulean, blackthroated blue, black-throated green, black and white creeper, chestnut-sided, redstart, oven bird, Blackburnian and Maryland yellow-throat warblers, also a Louisiana Water-thrush (probably a Louisiana), and whip-poor-will. 


\section{(Lake Forest)}

MAY I8, I90I. Twelve species warblers. Bay-breasted, black and white creeper, Blackburnian, blackthroated blue, Canadian, redstart, yellow, oven bird, Tennessee, Louisiana water thrush, chestnut-sided and magnolia.

May 12, 1904. Sixteen species warblers, all in Lake Forest village.

May i4, 1904. Saw from my window and porch ro species warblers. Redstart, black throated blue, Blackburnian, magnolia, yellow, Wilson's, Canadian, black and white creeper, Tennessee, black-poll.

May I4, I906. Sixteen species, Blackthroated blue, black-throated green, Blackburnian, black and white creeper, Canadian, chestnut-sided, magnolia, myrtle, Maryland yellow-throat, oven bird, Tennessee, yellow, Wilson's, water thrush, Louisiana water thrush, redstart.

May. 14, 1907. Thirteen warblers, forty-nine species in all, beside some herons, probably black crowned night, and a vireo, probably red eyed.

May 16, 1907. Sixteen warblers, fourteen of them on the ground on our place 


\section{Bird Observations}

'(the mourning on F. D.'s screen porch). They have been tumbling and flitting about the lawn all day, rarely in the trees. Such a view of warblers I have never seen. They were all so wonderfully tame, and would feed within a few feet of us. It was a moderate day as to temperature, a light westerly wind and partly sunny. Species: Black and white creeper, bay breasted, Blackburnian, Canadian, chestnut sided, Cape May, golden-winged, magnolia, Maryland yellow-throat, mourning, redstart, Wilson's, yellow, oven bird, and in the Durand ravine, Louisiana WaterThrush and orange crowned warbler.

May 23, 1907. Saw eleven species, nine of them close to the house. They were on the roof a great deal, dashing after insects. It was after twenty-four hours of heavy, wet weather. Blackthroated blue and green, Connecticut (male and female), orange-crowned (seen against the roof plainly), redstart, magnolia, Maryland yellow-throat, Cape May, Grinnell's water thrush, chestnut sided, yellow. This has been a cold, late spring and warblers are very late in going through. The trees, too, are not yet in leaf, so one can see them very plainly'. I

$$
\text { [28] }
$$




\section{Bird Observations}

saw many individuals of most of the above kinds.

May 27, 1907. Two Cape Mays, several redstarts, a Wilson, a chestnut-sided, a Canadian, and of course some yellow warblers all in our yard this morning; also at Mr. Day's and here, the magnolia, black-throated blue and Blackburnian.

May 28, 1907. This remarkable spring the warblers are still lingering and still mostly flying very low. Observed today the black throated green and blue, Cape May, Wilson's, magnolia, yellow, redstart, Canadian, Maryland yellow-throat, parula, a mourning (probably).

1908. A few myrtles and palms came in an early migration wave about the middle of April as reported by Mrs. Moss and others. (I was ill in bed.) This was followed by a remarkable spell of continued cold and northeast winds, from about April 23 to May 9, when very warm weather set in. This cold weather ended with several days of fierce northeast storm. No warblers were reported as far as I know in this period of over two weeks. I only saw one, (which I could not identify) and a water thrush, which I heard.

$$
\text { [29] }
$$




\section{- Bird Observations}

May II, I908. I saw eleven species and heard the water thrush.

May 27, 1908. Noted fifty-one species of birds: Wood thrush, bluebird, robin, northern yellow-throated, redstart and yellow warblers, Baltimore and orchard orioles, song, field, vesper and grasshopper sparrows, Dickcissel, goldfinch, scarlet tanager, redwing; yellow-headed blackbird, grackle, cowbird, flicker, red-headed woodpecker, indigo bird, red-eyed vireo, warbling vireo, barn and cave swallows, martin, brown thrasher, catbird, house wren, blue jay, cedar bird, coot, bittern, black tern, bobolink, phoebe, kingbird, crested flycatcher, pewee, meadow lark, shore lark, kingfisher, swift, mourning warbler, mourning dove, rose-breasted grosbeak, veery, chewink, nighthawk, oven bird.

May I3, 1909. Thirteen warblers. myrtle, magnolia, Tennessee, bla ck throated green, black-throated blue, black and white, Blackburnian, yellow, redstart, golden-winged, oven bird, chestnut-sided and Cape May. On May 14, 1909, fourteen warblers, same as preceding except myrtle and golden-winged, with parula, water thrush and Nashville added.

$$
\text { [30] }
$$




\section{Bird Observations}

\section{May 23, 1910. Noted eleven warblers}

from Kay's balcony.

May 22-23, 1910. First "rush", of warblers on our place; very cold May. June 5, 1910. Many migrant warblers still here. 


\section{AMERICAN BITTERN}

MAY 14, 1906. Found one roosting $M$ in a thorn tree not one hundred feet from the house. He sat there as long as we wanted to study him, and we came as near as we liked, he following us all the time with his strange yellow eye. He sat like a ten pin on the branch, his neck and bill stretched straight up and a front view looking like this :

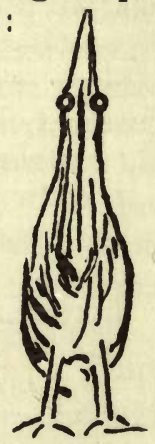

his eyes looking perfectly round, not foreshortened to an oval, a most curious and weird effect. He still sat there, immovable, when we left. What protective coloring. His stripes look like brown reeds, and his light colored bill looks like the tip of one.

$$
\text { [32] }
$$




\section{COW BLACKBIRD}

\section{April 3, 1894 \\ (Elmhurst)}

THE cowbirds mingle a good deal with 1 the grackles when migrating. They are easily distinguished from them by their smaller size and less conspicuous tails. The males have brown heads and necks and black bodies; the females are grey all over. They utter while flying a peculiar long whistling note, ending with a quickly repeated trembling note on a little higher key. It is rather a plaintive song -if it can be called a song - and is quite different from the scratching, cackling notes of most blackbirds. They only seem to practice this song a comparatively short time in the year, in April and May. I have also heard them utter a harsh rattle while flying, much like the rattled notes of the meadow lark. I think the females made this note but am not sure.

May, 1906. The males make a noise just like the gurgle of water through a long necked bottle.

\section{[33 ]}




\title{
BLACK-THROATED BUNTING
}

\author{
June 8, 1894 \\ May 7, 1895 \\ May 12,1896 \\ (Elmhurst)
}

THE incessant chee-chee-chee-chee-chee 1 of this bird may get monotonous when heard too often, but it is always a delightful sound to me. Its reedy quality attracts me; and it always means long June days and sunny prairies to me. It is essentially a denizen of the meadows. Few birds are more abundant or more prominent than these buntings are here. They mount on posts or tall grasses and shout at you energetically as you drive by, not in the least alarmed at your presence. In Lake Forest they are not so abundant. I only see a few birds out west.

May 27, 1908. I saw two and heard two more when going out to Libertyville today. I have not seen or heard one since I 904.

\section{[34 ]}




\section{BLUEBIRD}

\section{March 2, 1893 \\ March 3, 1894}

THE pair that built in my box in 1893 1 raised two broods. In I 894 they began building. May $3 \mathrm{~d}, \mathrm{I} 895$, I have seen no sign of a bluebird up to this time - May I3-and no one else has seen one here either. It is most remarkable. May 28 , still no bluebirds. July I 4, heard one warble today, the first one of the season. The latter part of July, I 895, I saw a family of six birds. September, r 895 , I heard one warble, the first one observed near our house this year, the others were seen on drives. 


\section{CARDINAL GROSBEAK}

I OBSERVED this bird first at Harrow1 gate, Tennessee, in April, 1894 , and became very familiar with him in Augusta, Georgia, in March, 1895 , and in other southern trips. But I had never seen him in our northern regions till today, April 4, 1902. A female has been seen with him by Emerson Tuttle, but I saw only the one bird, a male. He sang, and the song impressed me as very varied; the opening notes like a robin's warble, then a few chords, a warble too, but with the double sound which the veery has, only, of course, bold and loud. His whistles always have inflection in them.

April 15, 1909. Saw and heard a male cardinal at the Byron Smith's. He sang frequently, a loud clear whistle. Mrs. Burnap reported that she saw him yesterday and two females were with him.

June 5, 1910. A cardinal woke me with his loud sweet whistle this morning. Never heard one on our place before. He was in the maple by my window. He sang several times.

$$
\text { [. } 36 \text { ] }
$$




\section{Bird Observations}

June I9 and 26, I9I0. Sang both these days; must be nesting near here.

May 5, I9I2. Heard today and many days after on our place.

June I9 and 20. Again. 


\section{CATBIRD}

\section{May 4, 1894 \\ April 27, 1896 \\ May 8, 1897}

I THINK each year that I have learned 1 all the catbird's odd ways, but each spring as he returns he surprises me with some new vagaries either in song or behavior. He seems to revel in the unexpected.

May 30 1895. At $2: 30$ this morning I woke up and the first sound I heard was the soft singing of a catbird in the trees across the field. It sounded strange in the darkness of the night, and the strangest part of it was that he kept on singing in a broken, meditative sort of way for a full hour. By that time the first streaks of dawn began to appear, and the chorus of other birds drowned his voice. 


\title{
CEDAR BIRD
}

\author{
April 3, 1893 \\ (Elmhurst)
}

NOT a common bird here. Much commoner in Lake Forest. August 9, 190I. Found a nest in a nearby elm containing four eggs; how late in the season! 


\section{CHICKADEE}

August 25, 1893

(Elmhurst)

THESE birds do not seem as plentiful 1 here as the books report them in the east. The quality of their note, chick-adee-dee, is something like that of the chewink's call note, strident, but sweeter and of course much fainter and finer. The plaintive clear minor whistle of two notes, the first higher, the second a half note lower, I have also frequently heard.

April I I, 1903. A note I did not recognize at first I found to be that of this bird. It sounded like a blackbird in the distance. It was a decided cut-cut-ca-dacut strongly emphasized at the end, and rather harsh, not contented as a hen gives it.

\section{[40]}




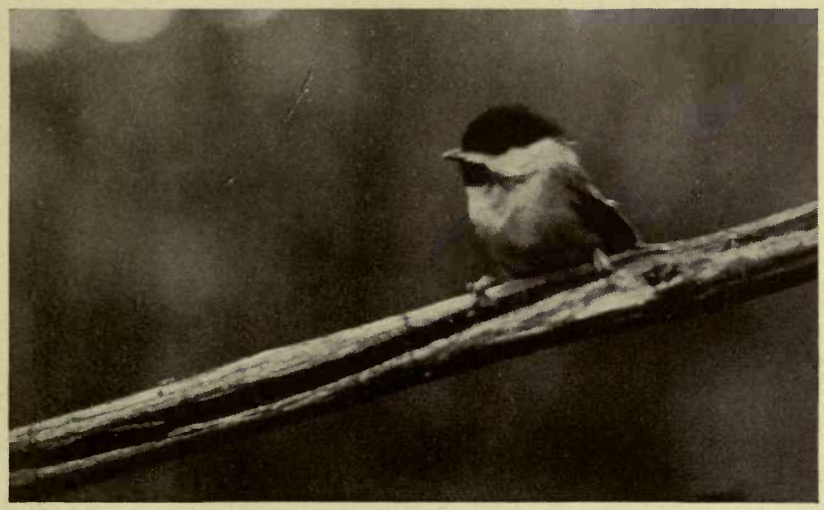

Young Chicadee 



\section{CAROLINA CHICKADEE}

\section{March 29, 1895}

\section{(Georgia)}

I IKE our northern bird, but without L the white edges to the tail. The note is described most accurately in Torrey's Florida Sketch Book, four notes, very sweet. 


\section{COWBIRD}

$M^{A Y} 24,1905$. Heard a loud rasping IV "ker-chee-e-e" in the woods, utterly unlike any note I ever heard a cowbird utter before. I felt sure it was some strange flycatcher note till I saw the bird. He uttered it many times, such a queer, grating sound. It never occurred to me it could be anything but a flycatcher till I watched the bird do it. 


\title{
BROWN CREEPER
}

\author{
Spring, 1893 \\ October 13,1893 \\ April 3, 1894
}

S AW one in Lake Forest as late as May

13 in 1907 .

\section{[. 43]}




\section{AMERICAN CROSSBILL}

\section{November $1, \quad 1895$ \\ August 23, 1896}

M $\mathrm{Y}$ attention was attracted this afterI noon by a flock of about twenty birds flying vigorously and directly towards some spruce trees near me. They were uttering a clear, whistling chirp constantly as they flew. I was sure they were birds I was unfamiliar with, and when they settled on the tops of the spruces and I brought my glass to bear on them I was delighted to recognize this long-looked for species. There were a few bright colored males, but most of them were the plainer olive females and the striped young birds. They were exceedingly tame, and were busily engaged in crawling up and down the branches and crunching the cone seeds in their bills. They made a decided noise with their wings when they fluttered about, louder than that of an English sparrow. Their crossed bills and short tails are conspicuous points.

August, 1896 . I saw a large flock today as I was sitting on the porch of our new house. I recognized them at once by the notes. Most of them were young birds.

$$
\text { [44] }
$$




\section{BLACK-BILLED CUCKOO}

$M^{A Y}{ }_{19}^{19}$ 1902. I find this species 1 much less common here than the yellow billed; saw one unmistakably this morning. 


\title{
YELLOW-BILLED CUCKOO
}

\author{
1892 \\ May, 1893 \\ May 14,1894 \\ May 13,1895 \\ (Lake Forest)
}

$A^{\text {PRIL 29, I90I. Had a fine view of }}$ his wings are and his bill looks as if it were all yellow and not just the lower mandible, at least it looks so in the sun. No notes from this bird today. I wish I could tell his notes from the black-billed. Was it this bird that has been giving a low coo at intervals for several days? (July $3 \mathrm{I}$, I90I) or the black-billed? I could only see that it was a cuckoo, not a bittern as we first thought. He keeps this cooing up for hours; so different from his loud cow-cow-cow-ing. 


\section{ACADIAN FLYCATCHER}

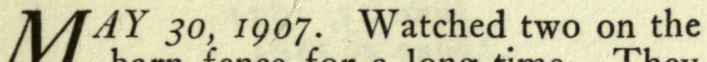
barn fence for a long time. They tilt their tails as the phoebe does, only it is a much more nervous and rapid motion than the phoebe's. A wood pewee was on the same fence uttering his sweet wail many times, and I could compare the two to great advantage. The Acadian looked so small and green beside the pewee. His wings were so barred and his eye ring so noticeable. 


\section{GREAT-CRESTED FLYCATCHER}

$$
\begin{aligned}
& \text { June } 13,1894 \\
& \text { June } 2,1895 \\
& \text { May } 8,1897 \\
& \text { May } 21,1898
\end{aligned}
$$

THIS fellow just lit on a branch near 1 me on the road to the spring for a minute, and then was off and away, and I saw no more of him this summer of 1894 . In Lake Forest, June 2, I 895, I again saw him and heard him give his loud wild cry, but I have not yet had a satisfactory study of the bird.

June 15, 1895. I had quite a good look at the great-crest today. The sulphur yellow is so conspicuous underneath.

May, 1906. When he flies he looks almost as long as a cuckoo. 


\section{LEAST FLYCATCHER}

$$
\begin{aligned}
& \text { May } 12,1893 \\
& 1895
\end{aligned}
$$

IN my four years of bird study (I 895) I have only observed this little fellow twice; never have heard him utter a sound. 


\section{OLIVE-SIDED FLYCATCHER}

M RS. HUBBARD pointed this bird 1 out to me once on a high oak in our yard. I do not know what year, perhaps about 1904 or 1905 , but I had a poor study of him on that day. Today, May I3, 1907, I watched him as long as I wanted to in a most favorable situation. He was perched on the dead stub of a tree, on the bluff on the Buckingham place, and as the tree was below me he was nearly on a level with me. He is a powerful looking bird. Such a strong bill, and such vigorous movements as he had! He would dart at insects a great distance away, but always returned to the same stub at the top of the tree. I noticed that he always faced south, no matter at what angle he lit on the stub he always took his position facing me and turned his eye towards the sun, which was bright and hot, without blinking. It was the same when I went to the west of him: he still faced south, so it was evidently not done with the object of keeping an eye on me. Was it that he saw the insects better between the sun and himself, I wonder?

$$
\text { [50] }
$$




\section{FLORIDA GALLINULE}

MAY $18,1902$. We were walking in W the McCormicks' ravine when I chanced to see a bird sitting perfectly still on a high crotch of a maple. We all viewed it through our glasses as long as we wanted to. Saw the leaden black breast and the brilliant red patch above the bill. It never moved, except to turn its head now and then for, I should think, twenty minutes. It looked like a rail, but I had never heard of one such an extraordinary color. Finally John and John Case threw stones to make it fly, but it simply craned its neck over to look at them. They banged the tree with a big stick, but it would not budge. Finally as we were turning to go it crept stealthily up the sloping branch of the tree, and settled itself in another position, where we left it, and hurried home to look up our remarkable bird. It uttered no sound of any kind. 


\title{
BLUE-GREY GNATCATCHER
}

\author{
April, 1894 \\ (Tennessee) \\ April 3, 1895 \\ (Georgia) \\ April 26, 1896 \\ (Lake Forest) \\ May 5, 1897 \\ (Lake Forest)
}

IN Tennessee when I saw this bird I 1 heard nothing but the soft little mew it gives as it flutters around among the branches. But here in Augusta I have had a fine view of two of these tiny birds and heard the song many times. Such a sweet, varied, soft, little song, something like a goldfinch's, but with almost as much variety in it as a thrasher's. It seems to me the faintest, tiniest little song and just suited to the size of the bird.

April, 1896. There are several of these little birds around our new house as it is building.

May 5, 1897. Saw a pair back of our garden.

$$
\text { [52] }
$$




\section{GOLDFINCH \\ January I4, I90I}

SAW and heard numbers of this species. 


\section{WILD GOOSE \\ January 4, I90I}

SAW a flock flying south and have seen them at intervals through December. 


\title{
BONAPARTE'S GULL
}

\author{
(Lake Forest)
}

April 28

W HAT a little beauty this gull is! His black head, pearl grey wings, and flashing white under parts are a pleasure to see as he wheels and turns over the lake. $\mathrm{He}$ is one of the smaller gulls, and is very graceful in his movements. 


\section{EVENING GROSBEAK}

$$
\begin{array}{ll}
\text { April } 16, & 1896 \\
\text { April } & 26, \\
1896
\end{array}
$$

FLOCKS of a dozen or fifteen of these $F$ handsome birds have been here (Lake Forest) since the first of the month. They are so tame it is easy to study them, and their call note, a loud, metallic whistle, without any inflection in it, proclaims their presence unfailingly. The note reminds me of one of the notes of the tufted titmouse. The whistle is accompanied by a sort of rattling trill at intervals. They seem to have disappeared now (May 5 ).

February 19, 1902. Saw a flock of fifteen, seven males and eight females in Fannie Tuttle's yard. They were on a bare spot on the ground under a maple, feeding on the maple seeds, apparently, and were so tame and close together that I had fourteen of them in the field of my glass at one time. The notes could be heard some distance away. The loud "peep, peep" reminded me of a little chicken's peep, when it is very loud, and the little softer rattle sounded like the soft rolled $\mathrm{R}$ a chicken gives as it cuddles

$$
\text { [56] }
$$




\section{Bird Observations}

under its mother's wing. The loud "peep" is more of a whistle than a chicken gives, but heard at a distance it reminds one of it.

March 3, 1902. Saw a large flock. Counted fifty-two and some others escaped me. There must have been sixty or seventy in the flock. They have been seen here constantly now for three weeks.

March 23. Still here.

April 4, 1901. Saw and heard many this morning. The rattled note reminded me of a car conductor's whistle.

April 15, 1902. Saw two full colored males and a number of females.

April I I, 1909. Saw several males and females. Have been here all winter, but this was my first view of them.

April I8. Still here; a large flock in the ravine near President Nollen's house. May 6. Heard several.

May 7. Saw seven grosbeaks and heard others. Seems remarkable that they are still here. It has been very cold up to May 5 , when it was $86^{\circ}$; May 6 , was over $70^{\circ}$.

May 14, 1909. Still here. 


\title{
ROSE-BREASTED GROSBEAK
}

\author{
Spring, 1892 \\ May 9, 1893 \\ May 3, 1894 \\ May 2, 1896
}

THESE birds are regular in their com1 ing, and are among our best known birds here, though they are never plentiful. The male is a beautiful singer, his sweet, melodious warble resembling a robin's, only it is much more finished, sweeter, with a softer and more oriole-like quality. $\mathrm{He}$ is one of our most constant and fearless singers during June. Later in the summer he is entirely silent.

September I, 1895. I heard one warble quite a long song, and as sweet in quality as his spring song. I have heard this bird sing exultantly as he soared in the air, after the manner of a bobolink. Both male and female throw themselves in the air and turn graceful somersaults in pursuit of insects. The male utters a loud chirp which is very unmusical, like the squeak of a wheel which needs oiling. The grosbeaks were very common here in the spring and summer of 1895 . One would hear six or

$$
\text { [ } 58 \text { ]. }
$$




\section{Bird Observations}

eight singing in the course of a morning walk.

May 15, 1901. Counted eight females and three males on Alcott school lawn. Miss Burt said that in the morning they counted thirty. 


\section{BLACK-CROWNED NIGHT HERON}

\section{(Elmhurst)}

THERE is a large and remarkable col1 ony of these birds which nests in the Bryan's place every year. They occupy the tops of the evergreens there, and the squawking clamor they make, especially towards evening, can be heard over here. They fly over our place every night about sunset, on their way to the creek for fish, uttering their loud "quauk" as they go; their white breasts gleaming in the light, and their wings "opening and shutting" with the regular flight which most water birds have.

June 15,1895 . I visited this heronry this morning and found the remnants of egg-shells thickly scattered on the ground under the nests. They were as large as hen's eggs, of a robin's egg blue in color. 


\section{GREEN HERON}

MYY 9, I90I. One sat on a small tree $M$ on the edge of our bluffs for about five minutes, and I viewed him through our big glass. He is a most curious and weird looking bird. His yellow iris and voracious looking bill give him an uncanny look. He hunched himself together and would then stretch his neck up to an incredible height. He looked much larger flying than sitting on the tree. This is the second one I have identified here. I saw his legs and feet very plainly and they certainly looked a bright flesh pink, not olive as the books say. 


\section{INDIGO BIRD}

$$
\begin{aligned}
& \text { July 20, } 1893 \\
& \text { May 7, I894 } \\
& \text { May 4, } 1896 \\
& \text { May I0, } 1897 \\
& \text { May I9, } 1898
\end{aligned}
$$

THE blue of the indigo bunting is very

1 different from that of the bluebird, darker and more metallic looking, but very brilliant in the sunshine. The light colored, thick bill is a distinguishing mark. Song a little like a goldfinch's - sweeter, less jumbled together, more of a "set song."

May 12, 1903. Saw four birds on the lawn east of house, three of them high colored, the other blue but not so deep and brilliant. Close to them were two goldfinches and a white crowned sparrow, a beautiful company. All were eating dandelion seeds.

May 30, 1907. Saw one male and two females eating dandelion seeds. What a reddish hue the lady birds have.

$$
\text { [62] }
$$




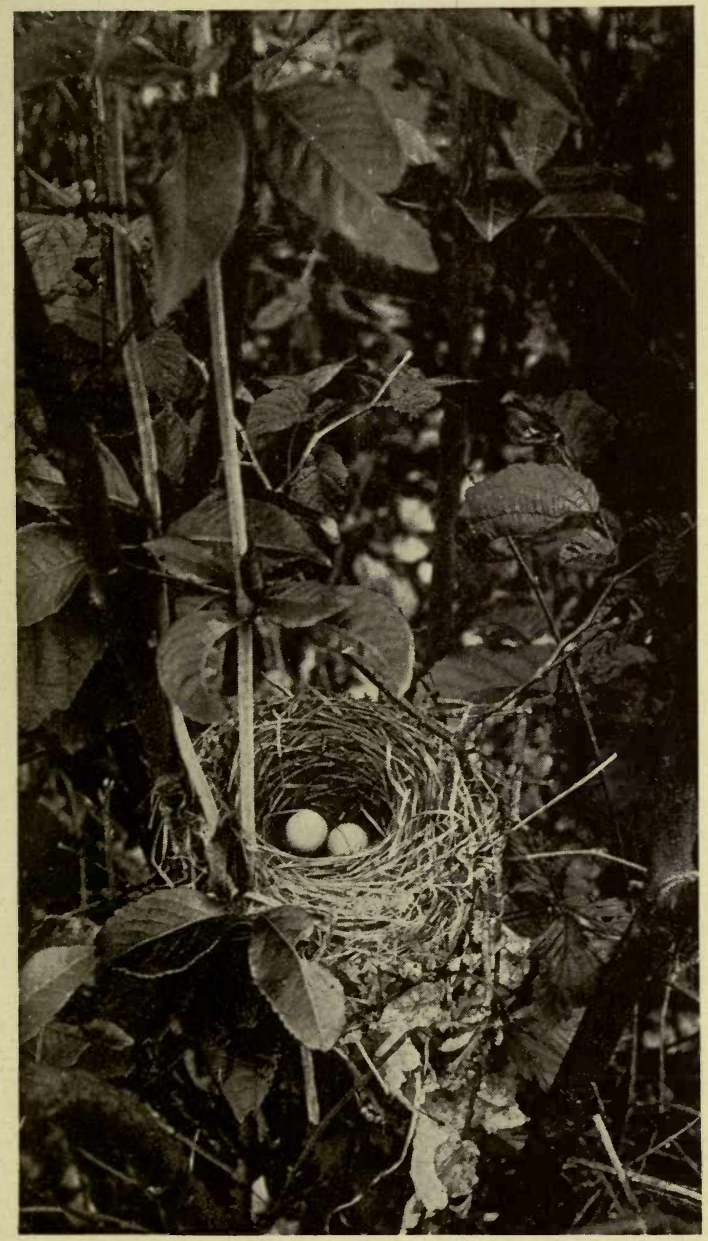

Nest of Indigo Bunting 


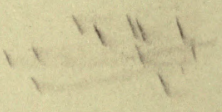




\section{JUNCO}

1892

\section{(Elmhurst)}

THE arrival of these flocks of slate 1 colored snow birds is always a sign of approaching winter. They feed on the ground. They utter frequently a low t'sip, t'sip, and sometimes the whole flock will light on the lower branches of a clump of evergreens and keep up a continuous low, sweet, twittering, which is pleasant to hear at a season when there are so few bird notes.

March, 1894. I watched one sitting quite high in a tree who threw his head back and sang with all his might. His song began quite like a canary's, with some little runs and trills, but did not have the variety or brilliancy of that songster, as he soon relapsed into his customary sweet twittering. 


\title{
KING BIRD
}

\author{
May 20,1893
}

(Elmhurst)

KINGBIRDS seem to fly out further K in their flights after insects than other flycatchers. Their motions are very graceful and beautiful. 


\title{
GOLDEN-CROWNED KINGLET
}

\author{
1892 \\ March 26, 1893 \\ March 21,1894 \\ December 2, 1894 \\ September 29, 1895
}

\section{(Elmhurst)}

THE stripe of vivid orange on the head 1 is always visible and not sometimes concealed as in the ruby-crowned. The note is exceedingly thin, scarcely audible at times. It is not at all shy and will often allow you to get within ten feet of him. The faint squeaking "zie" is usually repeated three times.

March, 1902. Have never heard any other sound from them except this ziezie-zie.

March, 1907. Heard a song I thought must be a warbler song, faint and uninteresting in character, but new. Found several gold crests and one or two sang frequently. I followed them for some time. Description in Chapman's Handbook excellent. First time I ever heard this species sing.

$$
\text { [65] }
$$




\title{
RUBY-CROWNED KINGLET
}

\author{
1892 \\ April 9, 1893 \\ September 22, 1893 \\ September 24, 1895
}

(Elmhurst)

THE smallest birds-these and the 1 golden crowned - in this part of the country except the humming birds and winter wrens. General coloring and habits much like some warblers, but they are smaller, and the shape is not so long and thin. The expression of the eye is quite different too, caused by a round yellowish mark around the eye, while the warbler's eye markings are usually horizontal. This gives him a wide-eyed, surprised look. The ruby lifts his wings constantly in a restless way, more than the golden. The ruby spot on the head is plainly visible all the time in the spring in some individuals, and is not concealed at all. Kinglets are much hardier than warblers, coming earlier and staying later. I have heard the ruby utter a harsh, chattering, scolding series of notes, much like a house

$$
\text { [66] }
$$




\section{Bird Observations}

sparrow, and quite loud. It is much like that of a winter wren. The song I have heard a number of times, a deliciously sweet fairy-like performance.

April 24, 1902. Heard three different individuals singing this morning. All had the chattering notes, interspersed with a hurried louder whistle, very like the "cher-o-kee, cher-o-kee" of the Carolina wren. This part of the song could be heard some distance, though of course it was not as loud as the wren's.

April 16,1903 . Saw a kinglet with a gorgeous ruby crown, and supposed a female must be near whose attention he was trying to attract, but I soon saw another male, also showing his ruby spot. There was a little sparring and then the one I had first seen flew away, his whole head looking like a living coal of fire.

April 27, 1907. Heard five kinglets singing this morning as I walked to Julia Thompson's. 


\title{
PRAIRIE HORNED LARK
}

\author{
Autumn, 1892 \\ June 28, 1893
}

(Elmhurst)

I SEE this beautiful bird here at inter1 vals through most of the year. I heard one sing quite a sweet little warble from the top of the fence when the ground was covered deep with snow. They utter a number of notes beside this warble. They have a lonely sounding "peep-peep" as they fly off from the road in scattering flocks, and they also utter some loud sweet notes, having a quality not unlike those of the meadow lark, though fewer in number. The yellow under the bill varies greatly in different individuals. In the birds where the color is pale, the species is probably the "Prairie" variety, the others the "Horned" simply. They are not at all shy, yet I have never observed them venture within the confines of a village. 


\title{
HOODED MERGANSER
}

\author{
April 28 \\ (Lake Forest)
}

SAW three in the lake; they dive like $S$ loons. The white back of the crest was most conspicuous, only it looked yellow in the strong afternoon sunlight. They stay under water quite a while, and throw themselves down, when they start to dive, with the utmost vigor. 


\title{
MOCKING BIRD
}

\author{
March 21, 1895 \\ (Augusta, Ga.)
}

THE song is so like that of the brown 1 thrasher, and yet it is more varied, and seems to me to have less of the bold dash of that bird, and more sweet melody in it. But it introduces more cat-calls and uncouth noises, so that it is not as dignified a performance as that of the brown thrasher.

April Ist. On hearing the song more often it seems less attractive to me than the thrasher's, though more remarkable. 


\section{RED-BREASTED NUTHATCH}

September 7,1894

August 29, 1895

I NOTICE a great deal of variety in 1 the coloring of the breasts of these birds. Some are as bright a bay as many robins, and others have only a pale yellowish-red wash over the white. 


\section{WHITE-BREASTED NUTHATCH}

\section{April 15, 1894 \\ (Tennessee)}

I HAVE never yet seen these birds in 1 Elmhurst (1895). I wonder why they are not here. The red-breasted I see every autumn. I enjoyed my one and only sight of this bird when I saw him in the Tennessee woods. He is too marked a bird to be mistaken for any other, even on a first acquaintance. In I 896, in January, I saw these birds in Lake Forest.

April, 1896. They are abundant here. 


\section{ORCHARD ORIOLE}

\section{June 8, 1900}

SAW and heard this bird today after $S$ having watched for him for nine years of bird study. Found him in a tree near Atteridge's farm, a mature male. Song beautiful, full, vigorous, rich, finer than the Baltimore.

May II, 1903. I have seen two orioles in our grounds for two days, and this morning I saw three, two mature males and an immature male of the second year, really a handsomer bird than the others with his trim olive coat and jet black face. The orchard oriole has a very difficult song to describe, a full, flowing warble, interjected with the characteristic blackbird note of the orioles at frequent intervals, but it is not loud enough to spoil the beauty of the song.

May 23, 1907. Saw a young male some days ago, in song, and today saw an old male in our yard. 


\section{GREAT HORNED OWL}

$A$ PRIL 22, 1902. Saw him in the ra$A$ vine back of the Henry Durand place (bird class). What a big fellow he is! And what remarkable ears or horns! A most weird looking bird. It is strange that in all my bird study I have seen so few owls. This and the screech owl are the only ones I am acquainted with. 


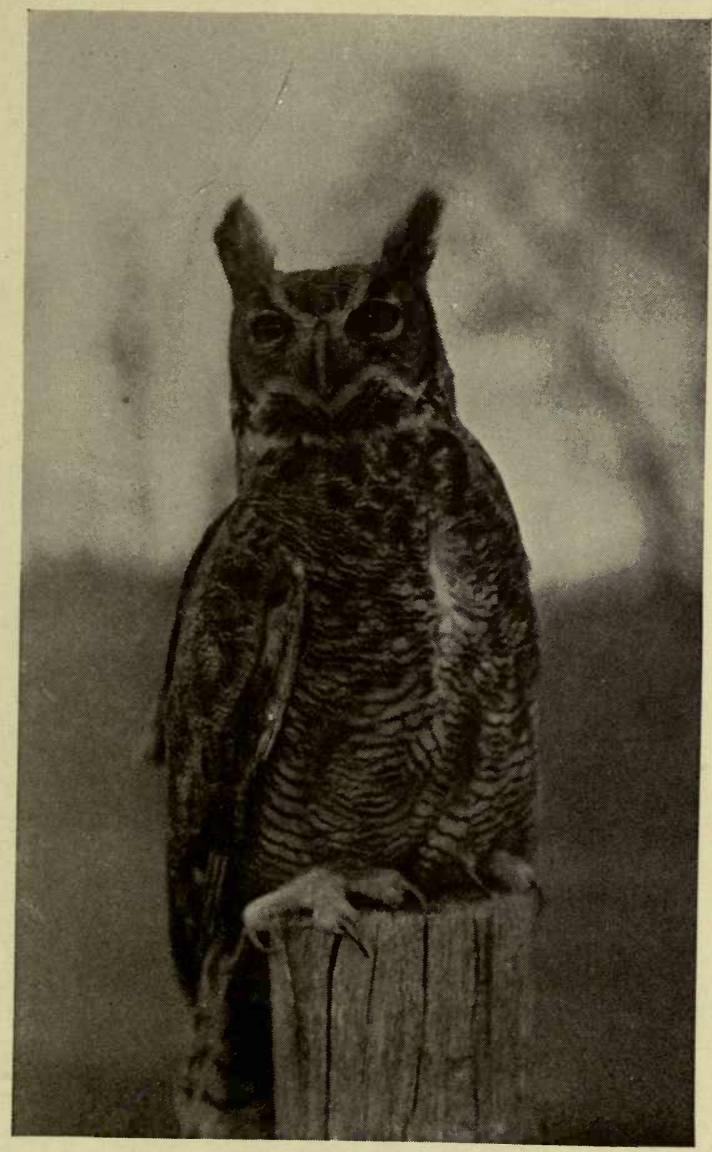

Great Horned Owl (captive) 



\title{
WILSON'S PHALAROPE
}

\author{
May 28, 1895
}

M RS. HUBBARD and I spied two of 1 these handsome birds in a small pond on the road to the spring. We had the most satisfactory study of them. They allowed us to come within about fifteen feet of them, and we watched them as long as we wanted to. There were two of them, both females, possibly, as these are described as the more brilliant of the two sexes. They were most conspicuous, striking birds, with their gleaming white breasts, black stripe through the eye, running into chestnut on the neck and back, and the broad white stripe on the back of the head and neck. They were most unconcerned about our presence, and went on wading in the puddle and feeding in the water as calmly as if we had been miles away. One bird was very belligerent to the other one and drove it away numbers of times. There was another smaller bird with these two beauties, apparently of the same family, but it was striped with grey and brown on the back, and plain white underneath, a sparrowy looking creature.

$$
\text { [75] }
$$




\section{Bird Observations}

He was quite unconcerned while the fights were going on between the other two. $\mathrm{He}$ tallied exactly with the description of the immature phalarope, but how could he have been that at this time of the year? On the whole I never had a finer chance to study a new bird than I did this time. The phalaropes uttered no sound except a plaintive "tweet, tweet," now and then.

\section{$[76]$}




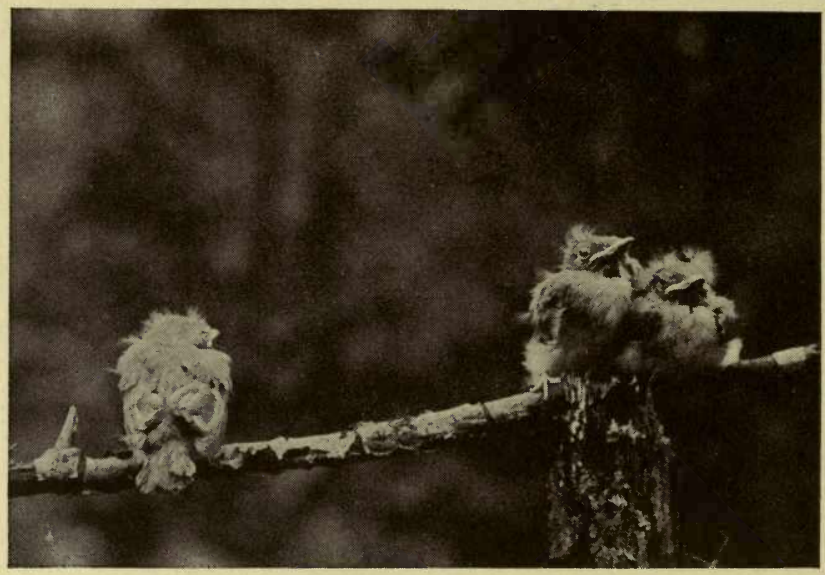

Young Phoebes 


\section{PHOEBE}

\section{6}

A PAIR nested on our west gable, $A$ before our Ardleigh house was finished.

July 6, 190I. This is the sixth year phoebes have nested on the house. I wonder if it is the same pair. Three years under the roof of the porch, twice under the porch, and once on the gable. This year they began nesting May I 7 th, began sitting June $3 \mathrm{rd}$, and the young flew July 6th.

April 20, 1902. Phoebes began nesting on the top of the porch pillar, their fourth year on this identical spot.

May $3 r d$. Began sitting.

May I7th. One just hatched, four other eggs in nest.

May I8th. All hatched.

June 2nd. Five lusty birds flew out of the nest today.

June $15^{\text {th }}$. The same pair (presumably) began to investigate the old nest again, and on the I 7 th I saw the female sitting.

1910. Phoebes still nesting on our house. This is the fifteenth consecutive year. 


\section{PINE SISKIN}

M $A Y 20,1907$. A flock of sixty birds, others I could not count scattered about feeding on dandelion seeds, was what I saw at the Winter Club this afternoon. A number of goldfinches were with them, but the siskins were much more numerous. Their notes first attracted my attention, a great deal of goldfinch like chatter, but with a constant burr or buzz interspersed with it, that distinguished it from the familiar song of that bird. I could get quite near the birds, they seemed unsuspicious, and to have the same gentle, confiding natures that the goldfinches have. How striped they were! All over, just the yellowish bars on the wings to break the effect. I wish we could induce them to stay and eat up our dandelion seeds.

May 14, 1909. A flock in the Granger's yard. The burr in the notes very noticeable.

\section{[ 78 ]}




\section{PIPIT \\ June 28,1893 \\ May 28, 1895}

W HEN I first saw pipits running along the road I thought they were shore larks. Their movements and size are so like the lark's. But a nearer view shows them to be very different. They appear dappled all over except on the lower breast, and they lack the black markings around the head which the lark has.

\section{[79]}




\section{PURPLE FINCH}

\section{October 1,1895 April, 1896}

F LMHURST has never yielded a single example of this bird, as far as I have yet discovered. I saw my first specimens in Lake Forest, John Ferry pointing them out to me. There was quite a flock of them feeding on the seeds of the ironwood trees. They were all in sparrowy dress, without the reddish hue they acquire later in the year. Their manners resemble those of the grosbeak, and they reminded me of the way that bird twists about after food, and almost crawls over the branches like a parrot. They look like small editions of the female rose-breasted. The thick bills and deeply forked tails of these finches aid in identifying them. In April, r 896, I saw them again in Lake Forest, this time the males had their rosy colors.

May, 1900. Am sure I heard the song, so loud and melodious, a little like the warbling vireo's; did not see the bird, but heard the song several times.

April, 1901. Heard the song numbers of times and saw the birds, later heard

[80] 


\section{Bird Observations}

them various times and saw one male in fine summer plumage, and he really did look very purple in the sunlight. The song, when I first heard it, made me think of a warbling vireo, trying to sing like a goldfinch. Such a variety of notes, and yet the song was short. A few days later the song I heard was more flute-like, louder, and fuller-but still short.

February 15, 1903. Saw a flock of about fifteen birds in our grounds. They were very silent. The males had a dusky purplish hue. There were several inches of snow on the ground, and it was still snowing. 


\section{CAROLINA RAIL}

$M^{A Y} 8,1905$, in the pond west of Libertyville, there must have been many of them.

May 15, 1906. One in marsh west of Convent Crossing, Lake Forest. Such a loud cackle of alarm as he gave, but looked as tranquil and tame as possible while he paddled about close to me. Why don't the books speak of his yellow bill, and of the Virginia's red one? The two birds were both together there. Some of their loud explosive notes make me think of a chat. 


\section{VIRGINIA RAIL}

$M^{A Y}{ }_{15}, 1906$. Saw my first one in IV marsh west of track at Convent Crossing. He cack-ed and kuk-ed, and waded about very near me. His bill looked so red. No book speaks of a red bill, but this one certainly looked so. 


\section{LOGGERHEAD SHRIKE}

\section{April 24, 1894 \\ May 28, 1895}

I NEVER see this shrike here in num1 bers, but it is a regular summer resident, and in my drives over the prairies I usually see one or two individuals.

May 28, 1895. We found five young shrikes, hardly able to fly, in a thorn hedge today. They were lovely little fellows, their plumage as soft as eiderdown, and they huddled close together, three of them on one branch, and looked as innocent of being members of a murderous race as if they were turtle doves. We found the remains of a small bird, supposably of a house sparrow, impaled upon a thorn near by their nest. The parent birds were nowhere visible, though we passed the place both morning and afternoon.

\section{[84]}




\section{NORTHERN SHRIKE}

\section{March 16,1894}

THE plumage of this bird seems dull 1 beside that of the Loggerhead, with its clear pearl greys, black and white, which I see here so often in summer. I have seen this bird only once so far. It sat on a lonely tree by the roadside and uttered a curious low-pitched gurgling noise, unlike any other note I ever heard. 


\section{FOX SPARROW}

S ONG varies very much in different in$S$ dividuals, always sweet, rich and melodious.

March 24, 1902. Singing in our grounds. The song has a decided melody and form. The first note single, several others in couples, then something of a jumble, a pure whistle. A quiet repose about it, though.

A pril 8, 1903. Watched one sing a long time. Such purity, such delicious sweetness of tone! Hardly any two songs alike, yet all about the same length, often ending with a little soliloquy, as it were, sometimes a slightly chattered note or two. All the songs had form, and had a large range of notes.

March $3 I, 1908$. So many singing, if one starts the whole flock begins to sing. The Asso. hymn "True hearted, whole hearted, faithful and loyal," recalls the form if you accent strongly the heart both times and the ful in faithful. 


\section{GRASSHOPPER SPARROW}

\section{June 21,1895}

I HAVE heard the feeble insect-like 1 trill of this bird several times, but have never been able to identify it till today. We were driving near Addison, and Edith Skeele and I heard the note and followed up the bird. He flew from one weed to another, singing with his head thrown back, and with an energy worthy of a better cause. His song is so weak, just a low trill, without any of the strident qualities of the chipping sparrow. It can only be heard a very short distance off. He is one of the smallest sparrows; the head showing the narrow median and the wider superciliary stripes very plainly; the wing tinged with yellow towards the front. 


\section{HOUSE SPARROW}

MY 29, 1902. A single pair are tryM ing to nest on Frank F!'s house. This morning I was awakened at 4:1 5 by the squawking of one of the pair, presumably the male. After listening to its monotonous chirping for ten minutes I was impressed with the number of times it repeated its note, and at what regular intervals it was uttered. I began to count the squawks, and counted one thousand one hundred twenty-seven of them with scarcely a variation in time or tone. Then it stopped for two or three minutes, began again, and this time I counted three hundred sixty chirps, when I grew tired of counting and went to sleep. At 6:30 when I awakened, the same bird was holding forth. 


\section{LARK SPARROW}

\section{June 25,1897}

SAW four or five of these birds in a field about six miles west of Lake Forest. They were singing when I first noticed them, a sweet song, something between a goldfinch and a vesper sparrow. Their marked heads and white bordered tails (the latter almost as conspicuous as a mourning dove's) make them easy to identify. They were very unsuspicious.

June 28, I897. Saw three more near Lake Forest. 


\section{SAVANNAH SPARROW}

$M^{A Y} 8$, 190I. Saw two sparrows which I took to be this species, but am not quite positive. Song, a faint whirr, but too little of it to tell. The yellow in front of eye most marked, but one of the birds certainly seemed to have a spot on the breast like a song sparrow. (No such mark in the books.) Its breast was quite striped. 


\section{SWAMP SPARROW}

MAY I, 1903. First view of this bird after all these years of bird study. He was in a swampy place west of the Walden gate. How he did flirt his tail and bob about! As active as a wren or a water thrush, indeed the tilting of his tail was very much like the latter bird. Then he would drop down into the grass and run through it like a mouse. He is smaller and more conspicuously striped than most of the plain sparrows, and the chestnut on head and wings is very striking. I heard no song, only a small weak chirp.

May 6, 1904. In our garden, a single bird, so restless and active. On first seeing it $f$ lit in and out of the bushes before I saw the colors, I thought it was a warbler. This bird chirped continually, not such a very weak chirp.

April 24, 1905. In our garden again, two of them, chirping constantly, quite loudly. Such restless, active birds, and so pretty. There were decided streaks on this bird's breast, not dark, very light, but plainly visible.

A pril 29, 1906. Close to our front door in the bushes-tilting his tail as usual.

$$
\text { [91 ] }
$$




\section{Bird Observations}

Colors so bright and rufous, such a chestnut crown. A pretty fellow indeed. Ran like a mouse between bushes, and was very active, but not as shy as some I've seen. 


\title{
TREE SPARROW
}

\author{
March 15,1894 \\ (Elmhurst)
}

M Y first sight of this bird was as I was I walking along the village road one windy morning. I knew him at once, he was so like the chippy, only he seemed warmer colored, and a little lighter. The reddish cap was very marked. $\mathrm{He}$ is a trim, aristocratic looking bird, much more so than the chippy, I think.

March 16,1894 . Saw a large flock, they sang a great deal, a very sweet song, but somewhat thin, quite varied, something of the goldfinch quality. They trill like a canary.

November 4. Saw spot on breast and two white wing bars, very distinct. 


\section{WHITE-CROWNED SPARROW}

$$
\begin{aligned}
& \text { April } 17, \quad 1894 \\
& \text { (Tennessee) } \\
& \text { May } 9,1896 \\
& \text { May } 5,1897 \\
& \text { May } 19,1898
\end{aligned}
$$

I HEARD this species sing for the first 1 time this morning, May 7, 1900. Again May 9th saw a flock and many of them in song. A very sweet, rather plaintive song, opening with a few notes in quality like the vesper sparrows, but in form a little like the meadow lark's, and ending with a few hoarse notes.

May 8, Igor. Saw seven birds on one small tree, nearly all sang. Quite a variety in their songs as to the pitch of the notes, but all had the clear meadowlark whistles first, and then the lower, harsher notes. A peculiar and distinctive song.

May I6, I90I. Waked up at $5 \mathrm{a} . \mathrm{m}$. by an unfamiliar song. A clear, sweet whistle, just like this :

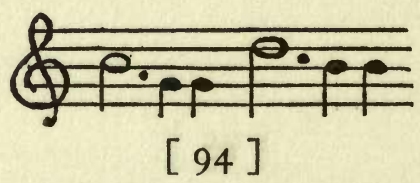




\section{Bird Observations}

No husky trill after it, yet I think it must have been the white crown.

May 18. Several here still, and singing, the song as when I first heard it, not the whistle. 


\section{ROUGH-WINGED SWALLOW}

\section{April 20, 1895}

(Washington)

I SAW numbers of these birds out in the 1 park, and watched some of them fly in and out of a nest hole in a high rocky bank. They are without the grey band across the breast which the bank swallow has, and are much the soberest of the family. They look so much shorter than the barn swallow, and gleam white and then brown as they fly in the sunlight.

\section{[96]}




\section{SCARLET TANAGER}

$$
\begin{array}{lr}
\text { May } & I 0, I 893 \\
\text { May } & 9, I 894 \\
\text { May } & 4, I 896 \\
\text { May } & 8, I 897
\end{array}
$$

I HAVE known the male of this species 1 ever since I was a child, but have never known its song till May, I 894. Its warble is like the robin's, but louder, more solemn, without the cheerful, everyday quality of the latter's song. It intersperses its song at times with its call of "chipchirr," which is such a marked and characteristic note. 


\title{
SUMMER TANAGER
}

\author{
April 9, 1895
}

(Georgia)

W.AS walking home to the Bon Air 1 today, and my attention was attracted by a curious clicking noise in a tree near by. It sounded like a chisel slipping on stone, not in the least like a whistle, or the trilling or warbling of most birds. I looked up and there was the summer tanager on a branch not far off. $\mathrm{He}$ is so handsome with his bright red plumage, though he does not look such a vivid scarlet as our tanager. He is smaller, too. $\mathrm{He}$ did not seem at all shy, and I had a fine chance of observing him. He uttered his clicking notes at intervals while he hunted about the tree for insects. They sounded like "kick-up," "kick-up" to me, and sometimes "kick-a-poo," the first notes higher than the others. They were not very loud.

April II, 1895 . Heard and saw him again today. This time he ran six or seven notes rapidly together, each with the sharp "click" to it.

April $13^{\text {th. }}$. Heard a tanager sing this

$$
\text { [ } 98 \text { ] }
$$




\section{Bird Observations}

morning. I heard this song like a robin at a distance and was sure it must be the tanager, and sure enough there was his red coat among the branches. I do not recall any other bird who sings so much like a robin as he does. The cadence and inflection of the warble seem almost identical with that of the robin, yet the quality is different, and has something of the scarlet tanager's individuality in it. I found, too, that the song is more broken than the robin's, being repeated at intervals, instead of being an uninterrupted strain.

April I 6 th. This tanager utters sometimes a curious squawking note very like a woodpecker. It is loud, and uttered at intervals from the top of some tall tree, so that until I discovered the small red object sitting up in a high pine and watched his bill open and shut I would not believe that there was not some new and large species of woodpecker up there.

\section{[99]}




\section{GREEN-WING TEAL}

\section{May 27, 1895}

THE only wild duck I have ever seen 1 around here, except the flocks one sees flying through the sky in the spring and fall. This solitary individual was in a marsh on the road to the spring. His chestnut head and neck, light back and breast, and the white crescent on his side just ahead of the wing, were his striking marks.

\section{[100]}




\section{GREY-CHEEKED THRUSH}

\section{May 12,1896}

THE absence of the yellow eye ring 1 is the only way to distinguish this thrush from the olive-backed. It sings a low, sighing sort of a song, here, not its full song.

$M a y{ }^{\circ} 12,1896$. I heard and saw one sing in this way. I have always thought these faint breathed notes, which I have heard so often issuing from the depths of some evergreen tree, came from the veery, but was undeceived today. It is a peculiar song, unlike any other, as if wet rubber were rubbed together; it rises a little and dies away, rises and dies away, in a sort of cadence-all as if it were singing under its breath.

May Ioth. I saw a thrush which seemed to be the grey cheeked and which sang in the same way, but this and the occurrence of 1896 as noted above are doubtless cases of mistaken identity. No doubt both birds were veeries, which goes to prove that that bird varies a good deal as to his coloring, and is by no means always so tawny.

$$
\text { [ IOI] }
$$




\title{
HERMIT THRUSH
}

\author{
Spring, 1892 \\ April 3, 1893 \\ October 11,1893 \\ March 22, 1894
}

VERY plentiful here during spring migration, apparently not so much so in fall, and more shy in latter season. The olive head and back and decidedly rufous tail make it easy to distinguish from other thrushes.

April 17, 1912. Was awakened at 5 a. $m$. by this thrush singing in a tree close to my window. Sang clearly about this number of notes :

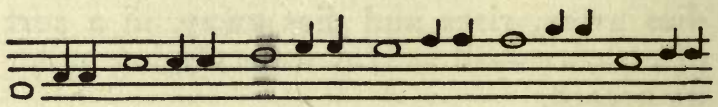

I have often heard the bird in S. W. Harbor, Me. This song was an unmistakable thrush song. It could not have been anything but the Hermit at so early a date. I did not see the bird, however, being ill in bed. I have not heard of its singing during migration in this locality before, neither had Mr. B. T. Gault, of Glen

$$
\text { [ } \mathrm{IO}^{2} \text { ] }
$$




\section{Bird Observations}

Ellyn, to whom I wrote. But he feels, as I do, that I have made no mistake in being sure that it is a Hermit. 


\title{
OLIVE-BACKED THRUSH
}

\author{
April, 1893 \\ April 28, 1894 \\ August 30,1894
}

THESE thrushes are here in great 1 numbers the first part of May, one of the commonest birds in the spring migrations. They come around the house constantly, in spite of the fact that there is almost no cover for them. I have studied them with great care, but find it difficult to be certain whether there are any gray-cheeked thrushes among them. The orbital ring does not seem very distinct in many of them, and yet they all have some, which the gray cheeks are not supposed to have at all. They utter a loud snapping chirp when alarmed. I heard one singing a twittering song softly to himself once, the way the tawny thrush does. 


\section{TAWNY THRUSH \\ (Veery)}

$$
\begin{aligned}
& \text { May } 19, I 893 \\
& \text { May } 11, I 895 \\
& \text { May } 16, I 896
\end{aligned}
$$

THE first acquaintance I had with this 1 thrush was in White Birch. It was singing softly to itself, in a twittering sort of way. I did not see it that day, but Mrs. Hubbard, who was with me, told me it was the Wilson's thrush.* Afterwards I saw the bird under an evergreen in our yard at Wheaton.

May II, I895. I had a fine study of the veery in White Birch. The bird hopped about on the road not ten feet from us, and stayed there as long as Edith Skeele and I wanted to look at it. It is so much more delicately colored than any of the other thrushes - the back and tail a light fulvous brown, the throat without spots, and the spots on the breast very faint. The markings about the eye and down from the bill are also exceedingly faint, not dark as in the olive-back and Hermit. The upper breast has a wash of decidedly

* See grey-cheeked thrush.

$$
\text { [ } 105 \text { ] }
$$




\section{Bird Observations}

tawny color across it, changing to whitish lower down on the breast. The veery is never as abundant here as the other thrushes.

May 16,1896 . I heard a veery give a loud, curious, whistle this afternoon, then a whining "whee-oo" several times, quite a different sound from any other note I ever heard from a thrush.

May II, I897. I found two veeries this a. m., both very easy to approach. They seem less shy than other thrushes. One had almost no perceptible spots on his breast, in the other they were quite distinct. Both uttered the peculiar complain. ing call. One made a series of odd whining clucks, then changed the key suddenly to a low one, and then changed again, so that he had quite a variety, and confused me at first as to what bird it could be.

June 26, IqII. Heard a veery near Stone Gate. Nearly every summer a pair nests in the woods west of our house. I have never found the nest, but I have heard them singing or giving their peculiar whining calls all through June and July.

\section{[ 106$]$}




\section{TUFTED TITMOUSE}

\section{March 20, 1895 \\ (Augusta, Ga.)}

THE notes of this bird resemble so 1 closely those of the chickadee that at first one cannot tell them apart. In appearance it bears a general resemblance to the cedar bird, but is smaller and less exquisitely colored. The titmouse has a clear whistle consisting of three, sometimes four, notes all on exactly the same key, and without inflection or variation, a simple, plain whistle, unlike the cardinal's in this. It also has a more common note, a whistle of two quickly repeated notes, the second note about four notes higher than the first; the two are generally given four or five times in quick succession. All the titmouse's notes seem to me to lack melody, and the pathos which is as characteristic of the chickadee's whistle. They are eminently prosaic. The notes always remind me of a penny whistle.

April IIth, Georgia. One feels as if there was always more to learn about the titmouse's notes. This morning I heard

$$
\text { [ } 107 \text { ] }
$$




\section{Bird Observations}

two or three notes squeaked out like a wheel of a barrow, and found it to be this versatile bird. 


\section{TOWHEE BUNTING}

$M^{A R C H}$ II, 1904. I saw one bird, and on the I2th I saw two males over near the Stone Gate, and another when I reached home, presumably three birds-remarkably early migration. 


\title{
PHILADELPHIA VIREO
}

\author{
1894 \\ April 5, 1895 \\ (Georgia)
}

SMALLER than the other vireos, except $S$ the white-eyed, or perhaps the warbling, this bird looks more like the latter, except that it is yellower. The breast, especially, is perceptibly washed with yellow on the sides. The song I have had a fine opportunity of hearing here in Georgia. It is quite unlike the other vireos, has more snap to it, beginning with a sharp "whit-tee," followed by some warbled notes. This is repeated several times at quite short intervals, and then a new refrain is taken up. Altogether the song lacks the monotony of the red-eye's entirely. Sometimes it begins with "whitwhit-whit" before the warble, each note sharp, and with the snapping quality of some of the white-eye's notes.

\section{[ IIO ]}




\section{SOLITARY VIREO}

MAY I8, 190I. Saw the second I have seen this spring. I rarely see more than one or two in a season and have never heard them sing. I think this is the most beautiful of all the vireos. 


\title{
WARBLING VIREO
}

\author{
June 12,1893 \\ May 9,1894 \\ May, 1895 \\ May 12,1896
}

A GREYER and slightly smaller bird A than the red-eyed vireo. I first saw this bird sitting on its nest in a cottonwood tree, warbling sweetly as it sat there (the males sit as well as the females). In I 893 . The birds do not seem abundant around here. I have observed perhaps half a dozen this summer.

June $2 I, I 895$. Edith and I saw another nest today, this time in an apple orchard. The bird was plainly visible sitting on it. The nest looked as if it had cotton on the outside. The song of these vireos is a lovely, smooth, flowing warble, meandering in rhythm something as the grosbeak's is. It is one of my favorite bird songs. It is soft and dreamy, quite unlike the energetic notes of the red-eye. 


\section{WHITE-EYED VIREO \\ April I, 1895 \\ (Georgia)}

THIS vireo is the last one of the vireos 1 (except Bell's) which I have learned to know. I have seen and heard sing, two of them this morning, and certainly they are the most extraordinary of the family as far as song goes. It is a curious sputtering performance, resembling that of the catbird, "only more so." This is the clown vireo, surely, and April Ist is an appropriate day to become acquainted with them. This species is as small as the warbling vireo. 


\title{
YELLOW-THROATED VIREO
}

\author{
1894 \\ April 5, I895 \\ (Georgia) \\ May, 1895 \\ May 4, 1896 \\ May 8, 1897 \\ May 12,1898
}

$W^{E}$ found this vireo nesting on the road to the spring, the male and female alternating in sitting on the eggs. Edith Skeele and I watched them for an hour, and it was very interesting to see one slip silently off the nest as the other came up. The coloring of this bird is very beautiful. The song is shorter than that of the red-eyed, deeper in tone, and not quite so varied and flexible, but it is richer in quality, and louder. In general character, however, it resembles the red-eye's song more than that of any other vireo. (I have not yet heard the solitary sing.) But I think it is, if anything, more deliberate and repeated at longer intervals. I have only observed one pair of these birds in Elmhurst, but in Georgia I have had ample opportunity to study them. Every

$$
\text { [ } \left.\begin{array}{lll} 
& 1 & 4
\end{array}\right]
$$




\section{- Bird Observations}

morning I hear one singing among the oaks in front of the hotel, and it keeps it up for hours at a time. 


\title{
BAY-BREASTED WARBLER
}

\author{
May 10,1894 \\ May, 1895 \\ May 29, I 897
}

THERE is no mistaking this handsome 1 warbler with his unusual coloring of rich bay, cream and cinnamon. There is no other warbler in the least like it.

May 24, 1894. Heard them sing their monotonous, saw-filing note, one of the poorest and weakest of the warbler songs. May I8, I90I. Saw several in the "chat woods." No song. They were uncommonly thick for bay-breasteds, which are usually a rare bird here in Lake Forest. Mrs. Hubbard and I must have seen at least four, probably more. 


\title{
BLACK AND WHITE CREEPER
}

\author{
1892 \\ August 30, 1894 \\ August 25, 1895
}

NO matter what other members of the warbler family fail to appear in the spring this one is always on hand. I suppose one reason one always sees him is that he is not at all shy, but allows a very near approach. I saw this bird in Tennessee and in Georgia when I was there, and in both places heard the thin, wiry song, a small, saw-filing sound, with the harshness taken out-one of the thinnest of bird notes. 


\title{
BLACKBURNIAN WARBLER
}

\author{
May 6, 1894 \\ May 7, 1895 \\ May 6, 1896 \\ May 14,1897
}

THE Blackburnian does not seem at all

1 shy in spite of his flaming throat and black and white stripes which make him so conspicuous. The song is not unusual, a little husky, and about the usual warbler length. I heard one May 24, I 894, which was a fine singer-for his kind-a jumbled succession of notes changing to another jumble four notes higher, rather longer than usual.

May 12, 1894. Saw several of these birds together today.

May 8, 1896 . One sang a jumbled succession of notes, about the usual warbler length, ascending in key, ending in an alternated, very high squeak.

May 12,1896 . Heard one sing just this way again.

May I8, I9oI. Saw five males and three females over in the "chat woods," and there must have been many more; none were singing.

$$
\text { [ } \left.\begin{array}{lll}
1 & 1 & 8
\end{array}\right]
$$




\section{Bird Observations}

May 17,1902 . Knew the song when I heard it today, a rising squawk at the end. Not a musical song.

May 7,1905 . The squeak at the end gets very attenuated and fine, and very high pitched. First part of song sounded very like redstart's. 


\title{
BLACK-POLL WARBLER
}

\author{
May 28, 1893 \\ May 12,1894 \\ May 7,1895 \\ May 8, 1896
}

I NEVER like to see this bird appear 1 because it means that the "warbler season" is nearly over, as it is usually about the last to come. This bird, though striped with black and white, as the black and white creeper is, is far less beautiful. The song is a little like the creeper's, but is more hesitating, and lacks the ease of the creeper's song. It is "saw-filing," though, and unmusical. It sometimes sings so low that it might be mistaken for an insect, but at other times it is quite loud, though never heard at much of a distance.

May, 189.4. A closer analysis of the song gives it did-did-did, hesitating, unmusical, staccato, not a "saw-filing" in time (that is, one note does not follow another as part of it, as in the song of the creeper and the bay-breasted; each note is separate).

May 14, I904. Seen against the grass what a brilliant bird a spring male is!

$$
\text { [ } 120 \text { ] }
$$




\section{BLACK-THROATED BLUE WARBLER}

1892

September 20, 1893

May 5, 1894

May 7, 1895

September 22, 1895

May II, 1897

THE plumage of all the warblers is 1 smooth and beautiful, but that of this bird particularly so. It is the darkest of all the family. The female, though green, can easily be identified by the fleck of clear white on the wings. Its chirp is an extremely fine thin squeak. The song is low, hoarse, and without the vibrating quality. I never see this bird in flocks, as the Yellow, Palm and Pine Warblers come sometimes, but in small numbers it is a very regular visitant.

May $I I, I 894$. The song is certainly like the opening notes of the black throated green's in quality.

May I8, I90I. I like his queer, coarse little song. It is usually three or four notes long. He is such a fearless fellow. He seems to prefer to work towards you rather than away from you in his tree peregrinations.

$$
\text { [ I 2 I ] }
$$




\title{
BLACK-THROATED GREEN WARBLER
}

\author{
May 10,1893 \\ September 22, 1893 \\ May 3, 1894 \\ September 6, 1894 \\ September I, 1895 \\ May 4, 1896 \\ May 8,1897
}

I SOMETIMES think this bird is hand-

1 somer than the Blackburnian, even, he is such a beauty, with his yellow sided head, green back and jet black $\mathrm{V}$ on his throat. In autumn this last is obscure or wanting, but the black stripes on side of breast are always plainly visible. The song is one of the most beautiful of all the warblers, more of a melody or tune in it, and with a sweetly deliberate quality in it. It has a lovely quaver in the middle notes, higher than the first and last. It is such a satisfaction to be able to identify this bird so unfailingly in the autumn, when so many of the family are so puzzling. 


\section{CANADA WARBLER}

$$
\begin{aligned}
& \text { May } 19,1893 \\
& \text { May I5, I894 } \\
& \text { August } 30,1894 \\
& \text { May I8, } 1896 \\
& \text { May 20, I898 }
\end{aligned}
$$

JEVER a common bird here. It is one of the many dark-backed, yellowbreasted warblers but the back is bluish instead of the usual olive, and the crescent of spots on the breast differs from the customary stripes of many of the warblers.

May, I 896. Heard its song, loud, jumbled, slightly resembling the indigo bird's; varies a good deal, often begins with a little whirr or snap.

May $3 I, 1901$. One has been singing at intervals all day here in our grounds. A bright, sweet little song, something of the red-eyed vireo's flexibility in it. He seems to me to say " $t$ 'le'we, t'lee we, t'le'we, t'lee we, t'l'it wit," but it is a difficult song to put into syllables. It has a more liquid and a more uncertain sound than the businesslike red-start's.

May 22, 1903. Has been singing for three or four days around the house.

$$
\text { [ } 123 \text { ] }
$$




\section{Bird Observations}

There have been several here today. Song as above described, varies a good deal in loudness, is sometimes not loud at all.

May 14, 1904. Two flitted close to me on our lawn for a long time. They usually appear singly, these birds, but this time these two males stayed together for an hour or two.

May 18, 1906. Several have been here for several days. At a distance one bird I heard certainly did sound a little like an indigo bird, but more liquid and less certain in form. He began often with "chipchip," twice or thrice repeated, and he often continued his song quite as long as the indigo does-it went on and on, as it were.

May 24, 1908. One sang at frequent intervals all day yesterday and today. Did not begin with a whirr or snap once; not as loud or bright or long as some individuals I have heard; uncertain quality very apparent, wavering, varied, no definite "form." Bird seemed very shy.

June 5. Two singing in my yard today, one been singing constantly for many days. They always stay here some time in migration. 


\section{CAPE MAY WARBLER}

$$
\begin{aligned}
& \text { May } 18,1893 \\
& \text { May } 12,1894 \\
& \text { May } 7,1895 \\
& \text { May } 12,1896 \\
& \text { May } 20,1898
\end{aligned}
$$

D

IFFERENT individuals vary very much, I find, in the brilliancy of the coloring. The brighter ones are beauties, The orange-yellow neck and side of head give it the appearance of a yellow-headed bird, almost as much as the black-throated green warbler. The chestnut ear patches are almost lacking in many specimens. They seem to prefer orchards; they are very plentiful at times. Song not remarkable, a thin but rather sweet squeak, repeated several times.

May, 1897. The song impresses me as one of the thinnest and least musical of the warbler songs.

May 7, 1905. What a study of one today, in the Joseph Durand ravine, just below us on a bare, small tree, a few feet away, as long as we wanted to watch him! $\mathrm{He}$ ran his bill industriously and faithfully up and down the twigs, eating bark lice

$$
\text { [ } 125 \text { ] }
$$




\section{Bird Observations}

eggs; they could not have been insects. $\mathrm{He}$ kept at this as long as we watched him, ten or fifteen minutes.

May 27, 1907. Many Cape Mays, male and female, have been in our yard since May 14th. This cold, backward spring prevents their going north. They seem to be a rather pugnacious bird, and are extremely lively, darting out at other birds and driving them off. They have been feeding in the barberry blossoms, and along the branches. They have a thin, sharp chirp, like the click of two pebbles struck together, quite characteristic.

May 19, 1908. Cape May's have been thicker than I've ever seen them this year. It's been cool and very wet, and a poor year for most warblers, but they seem to thrive. The females are abundant today, such dusky, striped birds. They feed so much on insects (supposedly) in the centers of the barberry blossoms and reach away out on the ends of the branches to get them. 


\title{
CERULEAN WARBLER
}

\author{
May 5, 1896 \\ May 8, 1897 \\ May 16,1898
}

I WAS attracted to these birds by their 1 marked song. Several were singing in the tops of the trees in our place where our new house is building. The song is four repeated notes, then four more a little higher in key, ending with a sort of burr-r-r. It has something of the quality of the black-throated blue's song. They all seemed to sing just alike, a quick, decisive song. The collar of grey blue across the throat is plainly visible on the white under parts (and the under parts are about all one sees of these dwellers in the tree tops).

May 6th. Heard them again-the four notes repeated first are all on one key-the last ones a quick, upward, chromatic run-ending in the burr-r-r.

May I 6 th. Still here, incessant singers.

June I8th. Still here. They must be resting here, it is so late. Heard numbers of them, and saw one on a comparatively low tree, the first good view I have yet

$$
\text { [ } 1227 \text { ] }
$$




\section{Bird Observations}

had. They were singing constantly and I find they vary the song a good deal. Sometimes it is shorter, and only two notes at first, but it always has that upward run, and that sweet whirring sound, like a little wheel. It is unlike any other warbler song, I think.

May 24, 1905. Heard one sing a song very like the red-start's "shree-shreeshree" in form, but the voice was the soft, husky, wheeling song of the cerulean. He sang many times and never had the upward run once.

May 2I, 1908. Watched one sing for half an hour, song like the one of May 24, 1905. No upward run. This bird came very near and moderately low, yet the blue never looked bright, always dull and greyish. I wonder if the individual males differ much in brightness of color, for it seems as if the dulness of some birds was not only because I did not see them in a good light. 


\section{CHESTNUT-SIDED WARBLER}

$M^{A Y}{ }_{18} 8,1901$. Saw a female-never remember seeing one before. She is a pale edition of the male, just a touch of chestnut, and her yellow cap duller. The male sang, a song almost exactly like the yellow warbler in form, but lacking the piercing quality of that bird's song.

May, I902. Heard a very full sweet song from this bird, quite loud, much more pleasing and rounder than the yellow.

May 19, 1907. The song struck me as very like the yellow's, but less piercing, and the finale had more of a twist to it. 


\section{CONNECTICUT WARBLER}

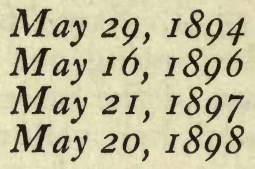

I SAW this bird first on a low tree in the 1 main street of Elmhurst. I followed the loud, ringing, wheedle-dee, wheedledee, wheedle-dee, supposing of course I should see a Maryland Yellow-throat, when what was my surprise to find it the Connecticut warbler. I watched it sing many times. The song is almost exactly like the Maryland. It is often repeated three times, sometimes only twice. Its ash-colored head and yellow breast and under parts, with no white on wings make it a sober bird. The ash terminating abruptly into yellow on the breast is the distinguishing mark, and the light ring around the eye enables one to identify it as a Connecticut and not a light-colored mourning warbler which it otherwise closely resembles.

May, I896. The loud ringing song attracted me again to this bird in Lake Forest this morning. It utters the first two

$$
\text { [ } 130 \text { ] }
$$




\section{Bird Observations}

notes without the third quite often. It is a remarkable song, heard at a long distance, but seldom uttered. It is a more vigorous and resonant song, than the yellowthroat's, but the form of it very similar. It is a hard bird to see, for though it allows you to come quite close it keeps constantly in the thick foliage, usually in hedges, or the lower part of spruces.

May 17. Have heard it again. On more familiar acquaintance it sounds more like "too-too-whit" than the syllables of the yellow-throat. Mrs. Hubbard is with me today, and has heard it too.

May, 1897. A fine study of the bird, the best I ever had. How loud and striking the song is! It seems less and less like the yellow-throat's. He shakes his little body all over when he sings, wings and tail vibrate furiously, and he throws his head away back. He sings from a low branch and then dives down into a thicket and is quiet for a time.

May 23, 1907. A Connecticut warbler stayed in the thicket south of our library window for a long time. I watched him through the long field glass. He stood for some minutes motionless on the ground, evidently watching some other

$$
\text { [ I3I ] }
$$




\section{Bird Observations}

birds in a tree. He looked like a little gnome or sprite against the dark background, and when he faced me he looked like a spectacled brownie with his light eye rings. He's a great bird to keep under cover and I never had such a long and satisfactory view of one before. 


\section{GOLDEN-WINGED WARBLER}

\section{May 25, 1900}

FOUND him after a long chase in the "chat woods" west of Fort Sheridan. The song first attracted me, and was many times repeated. An indolent, rather wheezy three, or usually four, notes, all on one note. Like the cerulean's a little in quality only, or a little of the blackthroated blue and green's huskiness. A lazy song, very distinctive, not loud, often repeated. Syllables that recall it to me, "S'h, hush, hush, hush," the last three slightly quicker than the first, but all drawled and insect-like.

June 8th. The same bird still in the same place. Can he be nesting? Sang just as constantly as before. Had fine views of him, and was struck with the vividness of his yellow crown.

May 14, 1901. Saw him in our own grounds and heard the song again. First description tallies exactly with the second impression, not always the case with bird songs. I have now seen this warbler three times this spring. He probably did not nest in the chat woods last year, as I never saw him after June 8th. 


\section{HOODED WARBLER}

\section{April 16,1895 \\ (Georgia)}

I FOLLOWED the loud song of this 1 warbler for a long time in the thick woods this morning before I discovered what bird it came from. It was a vigorous, rather short warbler song, sounding like the syllables in "Yes, yes, yes, I know it," with an upward inflection on the "I know." There were a number of these warblers in the woods but I only saw two. The song of the second was longer, and not so marked in its inflections, so that I did not recognize it as coming from the same species till I saw the bird. This is certainly one of the most striking of the warblers. The black hood, extending round both front and back of the neck and the back part of the head, encircles the brilliant yellow of the forehead and the part around the eye. The contrast makes the yellow appear more gorgeous than almost any other bit of warbler coloring, except, perhaps, the throat of Blackburn's warbler.

$$
\text { [ } 134]
$$




\title{
MAGNOLIA WARBLER
}

\author{
Spring, 1893 \\ May 8,1894 \\ May, 1895 \\ May 17,1896 \\ May II, 1897
}

THIS bird ranks close to the Black-

1 burnian and black-throated green warblers in brilliancy.

May I5, I894. I heard the song, quite sweet, warbled, something like the first "whee-chee-tee" of the Maryland yellowthroat, but it is broken off, in fact the bird never seemed to finish it. It is not nearly as long as the yellow-throat's song, but it is sweet and melodious.

May 24th. It varies its song a good deal, but retains the broken off, interrupted effect, and is always musical and sweetly warbled.

July 14, 1905. S. W. Harbor, Me. Song "whit-chee, whit-chee, whit-chee, wee-up," the last very hurried and broken at the end, the whole sounding at a distance as broken off and abrupt as the Acadian Flycatcher. Heard another song among the thick woods for days and days,

$$
\text { [ } 135 \text { ] }
$$




\section{Bird Observations}

but could never see the bird. Was it the magnolia? It said "whit-che-tee, wee-up," over and over again.

July 25, 1905. Female magnolia with insect in her bill chirped almost as loud and as harshly as a house sparrow, then changed to the usual warbler chirp, then to a faint " 'tsip" like a kinglet. She changed back and forth in these various chirps many times.

May, I906. Lake Forest. Yes, I think that S. W. Harbor bird was the magnolia without a doubt. This one said "veni vidi, vici" over and over to me, in the same tone of voice. 


\title{
MARYLAND YELLOW-THROAT
}

\author{
May 13,1894 \\ May 21, 1897
}

THESE warblers keep in the dense 1 thickets and evergreens, usually low down, so they are hard to see, but the song, as constant as the red-eyed vireo's, betrays their whereabouts. The song, well described by "whee-che-tee," three and sometimes four times repeated, is loud and seems to me to have more of the red-eyed vireo's quality than the warbler songs usually have. It is a vigorous and marked song. Yet I have heard the Connecticut warbler sing exactly like it.

May 14, 1906. This sang "wit-che-tee, wit-che-tee, wit-che-tee, wee-chee-hall-oree," a little variation after each thrice repeated wit-che-tee.

May 20, 1907. Saw a female Maryland yellow-throat today. Such a charming little creature as she was, carrying her tail like a little wren. She had quite a tinge of reddish on her forehead, and the yellow of the under tail coverts was plainly visible. She stepped along in the grass with such a dainty air-she seemed as pretty and winning as the male.

$$
\text { [ } 137 \text { ] }
$$




\title{
MOURNING WARBLER
}

\author{
May 27, 1898 \\ (Lake Forest)
}

HAVE watched for this bird all these 1 years and never seen him till today. The dark line around eye and back of it distinguishes it readily from the Connecticut warbler. No song heard.

May 26, I900. Saw a fine male, the breast markings very dark. Sang constantly, a pretty song, flexible, whistled, less in volume than the Connecticut warbler, but reminding one a little of it. It was repeated three or four times always, the syllables seemed like "hall-or-reé, hall-or-reé, hall-or-reé," and sometimes ending with a "whoit, whoit" on a lower key at the end. A slight resemblance to the oven-bird's, and yet so much less loud and beating. It is louder at the end, though, than at the beginning.

June 7,1900 . Heard him singing constantly in one place, but got a poor view of him. He was a regular will-o'-the-wisp and led me a chase. I never saw a bird seem so shy.

$$
\text { [ } 138 \text { ] }
$$




\section{Bird Observations}

May 29, 1903. Saw him and heard the song constantly, quality as described, but form different, more monotonous, less of it and not three times repeated, just four or five liquid notes, not to be described in syllables.

May 25, 1908. One sang for nearly an hour, and when I came back two hours later he was still singing in the same spot. The song was loud, and uttered with almost no variation the entire time I listened to it. It was a rapid, rolling whistle, "hallor-ee," three or four times repeated, the liquid, rolling sound being very pronounced, a noticeable and attractive song. Saw the bird well and watched him sing. $\mathrm{He}$ is a shy bird, though, and keeps well out of sight. I must have followed him three-quarters of an hour before I caught a glimpse of him.

May 27, 1908. Had good view of female-hard to tell from male Connecticut. -but the eye ring was not conspicuous nor consecutive. Throat was whitish in middle otherwise breast was a pure French grey color. Under parts quite yellow, a lovely bird.

June 6, 1909. Have seen and heard the mourning warbler several times since 


\section{Bird Observations}

May 28th on our place, near the house. Singing constantly.

June 6 th. Sang nearly all day.

[. 140 ] 


\title{
MYRTLE WARBLER
}

\author{
April 3, 1893 \\ September 20,1893 \\ April 22, 1894 \\ October II 1895 \\ May 5,1897 \\ April 17,1898
}

$7 \mathrm{HE}$ earliest to arrive of the whole 1 warbler family, and individuals either linger here or pass through up to the middle of May. They also stay here some autumns till the end of November. The white tail feathers and yellow rump show plainly while flying. It is less restless than most of the warblers, and sometimes sits still on a tree. The chirp is loud, and robust in tone, not a thin squeak.

April 21, 1898. Heard song for first time. Very varied, sweet, liquid, sometimes quite long. This bird sang constantly while I watched him, and it seemed as if he changed his song dozens of times. Yet it is a genuine warbler song, recognizable as such at once. 


\title{
NASHVILLE WARBLER
}

\author{
September 25, 1893 \\ May 9, 1894 \\ May 10,1897 \\ May 13,1898
}

THE coloring of the Nashville is 1 in plain washes without distinctive marks. Upper parts olive, head and sides of neck bluish ash, throat pure yellow shading to lighter yellow underneath. It is the yellowest of the plain warblers.

May 10, 1897. I heard its song, somewhat jumbled, a little like a goldfinch, but I only heard it a few times.

May, 1898. Had fine study of song. Description in Chapman's book perfect. First note very high, repeated several times, second note lower and uttered rapidly like a chipping sparrow's. Rather an insignificant and unmusical song.

$J u l y, 1905$. Heard a warbler-always invisible-for several weeks at S. W. Harbor, Me., sing over and over a never varying song - six notes all alike, then a rapid trill like a chippy. Was it the Nashville? It was not just like what I had

$$
\text { [ } 142 \text { ] }
$$




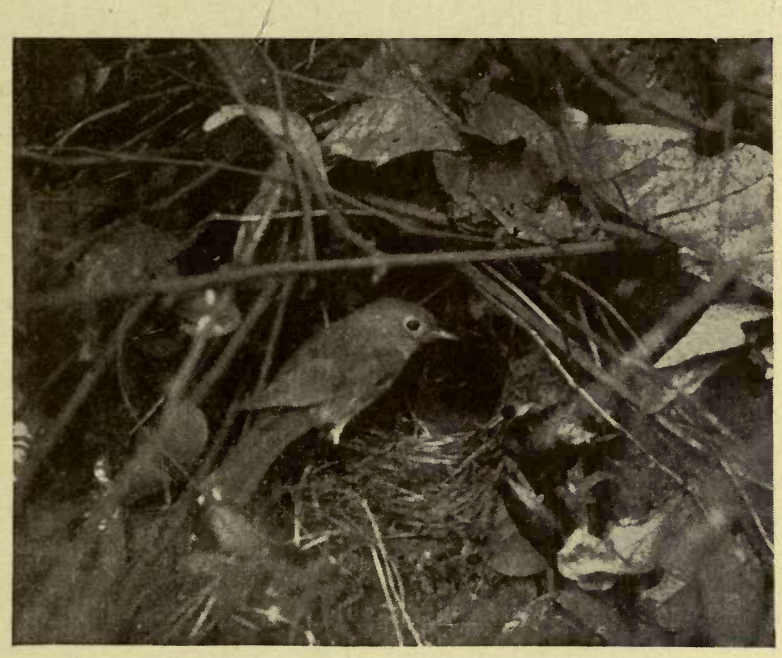

Nashville Warbler 



\section{Bird Observations}

heard before, and I never saw a Nashville once at $\mathrm{S}$. W.

May 9, 1906. Heard a song very like the above out my window, and looking out saw the Nashville, no doubt the Mt. Desert bird, but his song in migration is less pronounced and vigorous. 


\section{ORANGE-CROWNED WARBLER}

MY 16, 1907. Twice before I have 121. identified this bird, only once to my own satisfaction, but today I had a fine, close study of him, or her, I think it was. Such a darkish, dull bird, and perceptible eye ring, especially top and bottom, a small darkish line through the eye. Side of head all washed with olive, not separated into dark and almost white by a horizontal eye line as in the Tennessee. 


\section{OVEN BIRD}

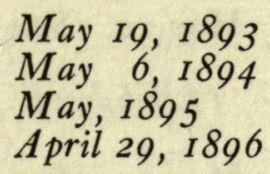

I ALWAYS see the oven bird here in 1 the village in the spring migration, and usually in the fall also, but in summer it takes to the thick woods, where its loud remarkable "whip-tee" can be heard rattled off with great energy at almost any hour of the day. In June, I 894, Edith Skeele and I found a young oven bird sitting serenely on a branch while the parent bird shouted in vigorous tones in the neighborhood. But the little bird was not at all afraid of us, and ate some large worms which we presented to it. 


\title{
PARULA WARBLER
}

\author{
May 10,1894 \\ (Elmhurst) \\ May II, I897 \\ (Lake Forest)
}

THE triangular patch of greenish yel-

1 low is plainly seen on the back of this bird. The throat and breast are golden yellow, with a wash of grey across the lower throat, and the yellow ends rather abruptly in the white of the under parts.

May II, I897. Only the second time I have seen this bird, and only one individual this time, and no song either time.

May 28, 1907. Heard two sing. Song a little like the cerulean's, but more rasping, not so deliberate, a trill, with an upward break at the end.

$$
\text { [146] }
$$




\title{
PALM WARBLER
}

\author{
May 5,1894 \\ May 6,1895 \\ September 29, 1895 \\ May 7,1898
}

THE chestnut on this bird's head is 1 almost as bright as that of the chipping sparrow and the line dividing this from the cheek quite as conspicuous only it is yellow. It is a very lively warbler, flirting its tail constantly, and running on the ground like a wren. It is remarkable how closely it resembles the Carolina wren when seen in this way.

Lake Forest, May 4, 1901. Watched a palm warbler sing this morning, the first time I ever heard the song. It is something between the chipping sparrow and the black and white creeper, a monotonous che-we, che-we, che-we.

April 27, 1906. Saw three, and two at least were singing, a rather canary-like trill, not a noticeable song. It likes the fences along the roadsides - and flirts in and out tilting his tail constantly.

\section{[ 147 ]}




\section{PINE WARBLER}

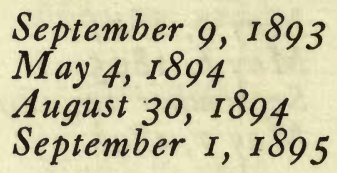

THE white wing bars are a distinctive 1 mark in identifying this bird. They seem more plentiful in the fall than in the spring. In September, I 893, the whole village seemed to be full of them. Their note at this time was the typical warbler squeak, uttered very often.

April 27, 1906, Lake Forest. The pine warbler does not seem to me as dainty and aristocratic a bird as most of his family. The one I saw today had very inconspicuous wing bars-hardly noticeable.

\section{[ 148$]$}




\title{
REDSTART
}

\author{
May 13,1893 \\ May, 1894 \\ May 7, 1895 \\ April 30, 1896 \\ May 9, 1897
}

THE redstart is supposed to nest here 1 but I seldom see it in summer, though it is always a common migrant in the spring. It always seems as if there were so many miniature males and females in proportion to the brilliant old male birds. The song is very like many of the other warbler songs (how confusing they are!) but it is apt to end its zie-zie-zie with a break at the end, giving it a sharp, unfinished sort of termination. Sometimes they sing as a black and white creeper does, a sort of saw filing, but not so thin in quality. 


\title{
TENNESSEE WARBLER
}

\author{
September 7, 1893 \\ May 8, 1894 \\ September, 1894 \\ May 6, 1896 \\ May 14,1897
}

SUCH a plain little warbler compared $S$ with the gayer members of the family! It it so like the warbling vireo in color, only the line through the eye is more obscure.

May 15,1894 . I saw this species sing frequently, a very loud song beginning with a sort of sawing two note trill, rather harsh and very staccato, but hesitating in character, increasing to a rapid trill almost exactly like a chipping sparrow's. A noticeable but not especially musical song.

May 10, 1895. I again heard many of these birds sing. They seem to be one of the most constant and vociferous singers of any of our warblers.

May 14, 1904. Seen against the grass this bird is far from dull. Head so bluish, and back so green, and all so soft and delicately tinted.

$$
\text { [ } 150 \text { ] }
$$




\title{
WATER-THRUSH
}

\author{
April 24, 1898
}

(Lake Forest)

GINE view of bird in the south ravine. $1 \mathrm{He}$ is so yellow below, especially towards the tail. His legs looked so pink and clean. I have seen this bird in Elmhurst (I suppose) at least twice, but have never been able to get a good enough view of him to be sure he was not the Louisiana.

April 23, 1904. Had fine study of one. Saw his streaked chin and dull whitish line over eye, sang constantly, always the same song: three notes "wee-wee-wee" (all same note) then "wee-chy, wee-chy"- not so loud and piercing - the whole song, I mean, as many I have heard. I hope I can learn the difference between the songs of the two water thrushes. Individuals differ so, it is hard to distinguish which species is singing. 


\section{LOUISIANA WATER-THRUSH}

\section{May 5,1897 \\ May, 1898 \\ (Lake Forest)}

I HEARD a loud, sweet song in our ra1 vine this morning and thought at first it was an indigo bird, but soon noticed that it was wilder and less regular in the opening notes. The song was repeated almost at regular intervals, like a warbler's song, but not quite so often. I only saw the bird once, but his whitish line over his eye was most conspicuous.

May II, 1897. He has been here constantly now for nearly a week. He confines his ramblings entirely to our ravine and occasionally a few neighboring ones. I have had a fine study of him this a. $\mathrm{m}$. which I have found a difficult thing to get, as he is extremely shy. He waded along the edge of the brook, singing from time to time, and showing his white throat and long superciliary white line most clearly. The song is about eight notes, uttered nearly all day. Two notes low, two high

$$
\text { [ } 152 \text { ] }
$$




\section{Bird Observations}

and then about four low again and more rapid. He left May 19 th.

June 21,1898 . Heard the water thrush again, so he must be breeding here. In May I saw several of these birds.

May 18, 1901. Identified one today past a doubt. Saw the white throat, and how white the breast was, compared with the short-billed!

April 20, 1902. Heard and saw one sing. Except for the three opening notes I never would have recognized the song. The first three notes were the usual clear, piercing water thrush whistle, but the rest was an intricate jumble of fine notes far softer, and of an entirely different quality, quite a song, not a brief note or two. He repeated this song several times, always beginning with the three piercing notes. I saw him finely, his white, unstreaked chin, and pure white underparts.

May 14, 1904. Song consisted of three notes "wee-wee-wee," then "whit-chee, whit-chee," followed by a confused and less loud jumble-reminded me of song of Canada warbler, only louder.

May 4, 1905. Close to me, no doubt that it was the Louisiana. Sang number of times, always the same, a liquid, rolling

$$
\text { [ } 153 \text { ] }
$$




\section{Bird Observations}

"wit-wit-wit," seven notes in all, louder in the middle.

April 20, 1906. Still struggling to tell the songs of the two water thrushes apart. Watched a Louisiana today - he sang the song exactly as heard May 14, 1904, except that the jumble did not usually follow. Heard a second bird sing an intricate low song, as if to himself, as jumbled as a goldfinch's, but with the "wee-wee-wee" thrown in every now and then. Thought this bird was a noveboracensis, but am not sure. 


\section{WILSON'S BLACK-CAP WARBLER}

$$
\begin{aligned}
& \text { May } 13,1893 \\
& \text { May } 21,1895 \\
& \text { May } 25,1897 \\
& \text { May } 21,1898
\end{aligned}
$$

THE first glimpse I had of this pretty 1 warbler was in the currant bushes at Cherry Farm in Elmhurst. He looked yellower than the books describe him, and with his jet black cap he was quite a conspicuous bird. I have not seen him again till May, 189.5 . The side view of his black cap makes him look as if he had a black stripe over his eye. This warbler seems to be one of our least common species.

May 13, 1895. Saw him again this afternoon on the road to the spring.

May 25, I897. Watched this warbler for an hour back of our garden. He came several times within five $\mathrm{ft}$. of me and was as friendly as possible. He sang repeatedly, a full, chord-like "chee-cheechee" followed by a goldfinch trill, varied somewhat as to this latter, but usually the prelude the same.

May 19th. The black cap has been uncommonly abundant this year. I have seen

$$
\text { [ } 155 \text { ] }
$$




\section{Bird Observations}

him four or five different times, and usually I see him but once or twice. Saw one sing today, a jumbled, not loud, warbler song, with a warbled or vibrating quality in it, not the "zie, zie."

May 28, 1907. This bird twitches his tail nervously with the rotary motion the cat-bird has, and also lifts his wings at the same time as the ruby kinglet does.

May 24, 1910, and later, been singing constantly, quality a little like mourning warbler's " 't'le, t'le, t'le, t'le, chee, chee, chee," quite loud and ringing, watched him sing.

\section{[ 156 ]}




\title{
YELLOW WARBLER
}

\author{
May 10,1893 \\ May 5, 1894 \\ May 7,1895 \\ April 30, 1896 \\ May 8, 1897
}

PLAIN golden yellow, the back tinged with green and the breast more or less distinctly streaked with brown. One of the few warblers that nests here.

May I8, I90I. How abundant this bird is at Ardleigh! At this time of the year redstarts and yellow warblers monopolize our woods. He always seems to me to say "hip-hip-hip-hip, hip-hurrahhurrah." 


\section{YELLOW-BREASTED CHAT}

\section{May 12,1898 \\ (Lake Forest)}

I HAVE been watching for this bird for

1 years but have never seen it till today. I rode out to the woods west of Ft. Sheridan and while there heard the queerest loud whistle followed by a rapid scolding. As this issued from a thick bush I thought of a chat at once, but could see nothing. This whistling and scolding was repeated at intervals from various parts of the wood and I followed, determined to see him if possible. But after following the queer sounds for an hour or so I was just giving up and going home when there he was on a low bush some distance ahead of me, but near enough to see his gorgeous yellow breast clearly. He hopped about and stayed long enough for me to see him as much as I wanted to, and came nearer so I could distinguish all his markings. His "song" is certainly the most remarkable one I ever heard. All his notes are so loud and imperative. $\mathrm{He}$ whistles as clearly as a quail, but louder, chatters like a giant

$$
\text { [ } 158 \text { ] }
$$




\section{Bird Observations}

wren, caws like a crow, and makes queer guttural sounds that are unlike anything I ever heard. It is all so loud and each note so distinctive and different that the variations of a catbird or brown thrasher sink into sparrow twitterings beside it.

July 2-5, I 898. Heard him again, on second date heard two birds. (Was one the female?). One sang a much louder and more varied "song" than the other. It was in the Ft. Sheridan woods. He must have nested here.

May 12, 1902. Mrs. Moss and I heard one just west of the Chat woods, and after stalking him for a short time saw him on a bare tree where he sat and jerked out his ejaculations for a long time. He afterwards changed to two other trees, in both of which we had simply perfect views of him. He pumps himself into this position

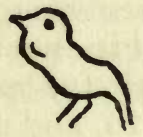

when "singing," with his throat and rump protruding most grotesquely. I never had a better study of any bird. The mate answered him, so I hope they will nest here again. The unmistakable and constantly

$$
\text { [ I 59] }
$$




\section{Bird Observations}

recurring "kouk" in his song makes it easy to identify, not to mention its other peculiarities.

[ 160 ] 


\title{
YELLOW-THROATED WARBLER
}

\author{
March 29, 1895
}

\section{(Georgia)}

I CERTAINLY thought I saw this 1 handsome bird in Elmhurst a year ago, and yet it had a striped back. I cannot be sure that I did. This one in Georgia has a blue-ash back, and with the black triangle back of his eyes, and his bright yellow throat is certainly almost as beautiful as the magnolia warbler. His song was quite loud, and varied, usually about six or eight notes and then a trill on another key. An unmistakable "warbler song" to my way of thinking, and not like the indigo's as the book says.

April ${ }^{1} 5,1895$. I saw this bird again here in Georgia and the song this time consisted of several notes ending in a trill very much like a chipping sparrow.

\section{[ $16 \mathrm{I}]$}




\title{
WHIP-POOR-WILL
}

\author{
May 8, 1897 \\ May 7,1898 \\ (Lake Forest)
}

I USED to hear these birds constantly 1 around our old farm at Winfield, and once I think I saw two of them. But here in Elmhurst I have never yet ( 1895 ) heard one.

May 8, 1897. Kitty Pomeroy and I started up a whip-poor-will in the ravine. It lit on a branch near us, and sat there as long as we wanted to look at it, and then as we came near it flew off as silently as a bat. In the evening we heard two answering each other in the thick woods. They are plentiful here (later).

May 17,1901 . One flew down on the walk twenty $\mathrm{ft}$. from where we were sitting. He seemed to lie sidewise on the path instead of perching, and after a minute or two flitted silently away.

$$
\text { [162] }
$$




\section{CAROLINA WREN}

April 30, 1894

(Elmhurst)

SAW a pair feeding in the Sturges $\checkmark$ garden, mostly on the ground, but they frequently flew into a tree, when the male would throw back his head and give a sweet, twittering wren song, not nearly so exultant or gushing as the house wren's. $\mathrm{He}$ sang this song many times and did nothing else. These birds appear quite unlike the other wrens, being larger, and the rusty yellow under parts, the long dark streak over the eye, and the rump much brighter than the rest of the back (the one I saw looked almost greenish red), distinguish it from the house wren or Bewick's wren. These birds when on the ground would run very fast, and every now and then would flirt up into the air with a regular redstart rush and tumble.

May $3 r d$. Have seen them again. The male sang as before, nothing else.

Spring, 1899 and 1900 . Saw and heard this bird frequently in Virginia and North Carolina. Do not feel sure of it always

$$
\text { [ } 163 \text { ] }
$$




\section{Bird Observations}

as distinguished from Bewick's, as far as the song is concerned.

August 13, 1900. Was awakened about five a. m. here at Ardleigh by the clear whistle "willy-way, willy-way, willy-way," outside of my window.

August 22nd. Still here, have heard him several times in the garden, but have not seen him yet. Heard him up to the last of September at intervals.

October Ioth. Saw and heard him again, good view of him.

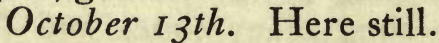

June 27, 1901. Heard him again.

August gth. Has been here at frequent intervals since June 27 th, and several times I have seen two birds.

November 24th. Heard again!

December I7, I901. Heard a vigorous "wren scolding" and saw a Carolina wren sitting on the woodbine on our east porch. He stayed there ten or fifteen minutes, and seemed to be pulling off bits of bark. I could not detect any berries. He was cold, and sat down on his feet a great deal. It was only $\mathrm{I}^{\circ}$ above zero, and it was $-13^{\circ}$ two days ago. He did not sing, but scolded a great deal, and bobbed his tail over his head. He let me come very near.

$$
\text { [ } 164 \text { ] }
$$




\section{Bird Observations}

His tail and wings and rump were very rufous, the breast slightly washed with yellowish rufous, and the light stripes over his eyes were very grey, not white.

May 19, 1902. This bird has been here for weeks and is undoubtedly nesting here. How I wish I could find the nest! Saw a pair in the McCormick ravine, near the lake, $a \cdot f e w$ days after this last entry.

June 24th. Heard the song for the first time since last note.

October 30, 1902. The wren has been here at intervals all the fall. This a. $\mathrm{m}$. I saw two, presumably a pair. One sang steadily for nearly twenty minutes, changing its song many times. He would repeat the same roundelay several times, and then start on another, repeat that, and so on.

August 12, 1908. Heard one again, after an interval of four years in which I have not seen or heard a trace of one. Twice a few days before this date I thought I heard one in the distance, but this a. $m$. he was close by and singing loudly.

August 14th. Still here.

July I, I goo. The wren has been here all the spring and sung constantly. $\mathrm{He}$ must have nested in the near vicinity. Is still singing daily.

$$
\text { [ } 165 \text { ] }
$$




\title{
WINTER WREN
}

\author{
April 8, 1897 \\ (Chicago Heights) \\ Fall, 1897 \\ April 17,1898 \\ (Lake Forest)
}

I GOT a fine study of this wren on my 1 first sight of him. He stayed in a hollow of the wood as long as I wanted to look at him, and frisked about not ten feet away from me, peering out at me every now and then, but otherwise quite unconcerned.

April, 1898. Heard a fragment of its song, too little to tell much about it, and he would not repeat it.

October 8, 190o. One bobbed at me from a nearby branch most vigorously, and scolded me well. He chirped a great deal, two chirps uttered in quick succession, the last a note higher than the first, quite a distinctive, double sort of chirp. His scolding, a small chatter, reminds me of the ruby crowned Kinglet's.

$$
\text { [ } 166 \text { ] }
$$




\section{Bird Observations}

December 8, 1907. A winter wren came on the porch this morning and flitted in and out of the railing and sat on the top of it for some time. It was a mild day, no snow. I have never seen one so late before. 



\section{BIRD OBSERVATIONS IN EUROPE}



BIRD OBSERVATIONS IN EUROPE

July, August and September, 1906

ULY 16th. Stormy Petrel. A small flock flying back and forth at the stern of the ship in mid-ocean. They looked so small and so black, and the rump so white. They flew like martins, and kept close to the water. They followed the ship for some days.

July 2oth. Herring Gulls. Seen before land was in sight. As we came nearer land they came in crowds, and followed the ship for food.

July 20th. Lesser Black-Backed Gulls. I felt satisfied it was this species that mingled with the herring gulls-though their backs were not black, but brownish, not in full plumage yet.

July 20th. Puffin. Close to the English coast one of these queer birds was sitting in the water. His bill gave him the effect of wearing a red mask, and he looked like a clown. He half tumbled, half flew out of the way of the ship.

July 2 Ist. House Sparrow. First bird

$$
\text { [ I 7 I ] }
$$




\section{Bird Observations}

heard in France, and noted in many cities and villages afterwards.

July 25th. Vevey. Black-headed Gull. Numbers of them sitting on the blue waters of Lake Geneva, and later in the morning flying gracefully over it. Handsome birds, beautifully marked, and giving a most charming effect seen against the turquoise blue of the lake with the mountains for a background.

July 25th. Vevey. Swallow. Many flying about the hotel and over the lake, pretty fellows, and though marked rather differently from our barn swallow looking much like it as they fly.

July 25th. Vevey. Martin. Associated with the swallows, but the white rump and much less deeply forked tail made it easy to distinguish. Smaller than our martin, only five and one-half inches.

July 26th. Vevey. Greenfinch. Saw one close to the hotel, all olive green and yellow, saw the yellow rump plainly. He had a very heavy bill. He sang a very sweet song, trill after trill, on varied keys, all soft and attractive, sometimes a warble introduced, but mostly the trills.

July 27th. Vevey. Common Buzzard. He has been sailing over the lake daily,

$$
\text { [ } 172]
$$




\section{Bird Observations}

a sinister, dark bird, his wings flapping like a crow, sometimes soaring; tail long, a falcon beak, the ends of his wings having the quills spread apart like the fingers of a hand. He seemed to be looking for food from the ships, I thought, for he would dive down once in awhile, as if he were pouncing on his prey.

July 3oth. Zermatt. Swift.

July 3oth. Zermatt. Saw large black or very dark birds, larger (I should think) than a crow, soaring over the mountains at the Staffel-Alp, a dozen or so. They had conspicuous yellow bills. What were they? Do not think their bills were hooked like a hawk, but am not sure. (This was Coracias des Alpes, Fregilus graculus.)

July 3oth. Zermatt. Chaffinch. Saw a handsome male in the road, and later near the hotel a female feeding a young one, no song.

August 27th. Common everywhere.

August Ist. Baveno, Italy. Black-Cap Fauvette. Studied songs of two birds, both undoubtedly blackcaps (Sylvia atiëcapilla) though they were difficult to see, as they kept in the tops of high, thick trees. But I had several fairly good views of

$$
\text { [ } 173 \text { ] }
$$




\section{Bird Observations}

them, and could see the blackcap, slender black bill, ash grey breast, and the greyish olive back, no white marks. Movements were like our vireos', only a little quicker. They sang in the garden back of the hotel from $6 \mathrm{a} . \mathrm{m}$. to $7: 30 \mathrm{p}$. m. with no very long intervals. I never heard so much song from any species. Song varied very much. Heard at a distance, or when sung softly it was much like our warbling vireo's. When full it was much more vigorous, brilliant, varied, and with an oriole quality. At its best it was as loud and lively as a Japanese robin's. The ordinary intervals were about the same length as a warbling vireo's. Often the bird began with a few sputtering notes, and he introduced a great many small chips and chirps between the songs. Sometimes he would whistle three or four notes all on one note during his song, quite noticeable. Song usually "worked upwards" in key as a ruby kinglet's does, - as the song went on-higher at the end than at the beginning. Still this was not always so. There is quite a suggestion of the purple finch in it. At its best it was a loud, noticeable and very beautiful and varied song. Birds seemed very shy, though they sang over my head

$$
\text { [ I74] }
$$




\section{Bird Observations}

for hours, but almost never came low, only saw one do it once. The two would answer each other as they sang. A most interesting study. The day was very hot and sunny, but it did not seem to affect them.

August 2nd. Heard them again all day and got several views of one, also a female. Kay saw them too, black cap of male very distinct as he leaned his head down. We were doing nothing but staying in the garden, as it was very warm, and it took long patience to see the birds. One male, while he flitted about a good deal, seldom left the vicinity of four or five trees near where we sat.

August $3 r d$. Baveno. Isola Madre. Heard a loud, bright, challenging song, sung over and over, beginning with several rapid notes all on one key, and then a warble, all bright, noticeable, and gay. The gardener said it was a "fringuello," chaffinch, and I believe it was.

August $3 r d$. Baveno. Saw gulls in the lake, all the primaries tipped conspicuously with black, and just like description of the Common Gull.* Also saw terns, but could not tell which kind.

* Ltens ridibundus have black primaries and often no black on head. 


\section{Bird Observations}

August I5th. Lugano. Gold crest? Heard in the tops of the pines, same note, it seemed to me, as that of our kinglet.

August 20th. Tellsplatte. Lake Lucerne. Spotted Flycatcher. No mistaking this fellow, so like our flycatchers in his ways, and general appearance.

August 20th. Tellsplatte. Nuthatch. More like our red breasted than the white in coloring, heard no note.

August 20th. Tellsplatte. Willow wren probably. (or Chiffchaff?). Had a fine view of this bird, as he was most confiding. Color of back seemed a duller olive than the willow wren's, otherwise description the same. There was a dark line through the eye as well as the yellowish one over it, and the primaries were some of them yellowish, and others dark. No white on tail or wings. No song heard. Also saw a tit today, but could not identify it. Must have been the blue or marsh tit, seemed rather a greenish bird in the light I saw it in.

August 23rd. Grindelwald. Crow.

August 23 rd. Grindelwald. Pied Wagtail (?). Only a glimpse of a slim light colored bird with a black throat and neck (looked like a black bib), long tail, rather.

$$
\text { [ } 176 \text { ] }
$$




\section{Bird Observations}

Saw the black throat and breast unmistakably and don't think there is much doubt that he was the wagtail.

August 27th. Grindelwald. Great Titmouse. Notes very varied, some of them like our chickadee, a very pretty bird, and a very active one. Saw also today a bird that looked the size and type of a bluebird on a fence, close at hand, slaty grey, very dark all over, no white, except lighter on belly, under tail and back of belly certainly seemed to be a chestnut. Eye and bill and legs very black. No white marks. Bird seemed to act like a thrush, but too small for the blackbird. What could it have been? Seemed shy.

August 27th. Spiez. Blackbird. Sooty black all over, except head brown on top and breast darkly mottled with brown. Size about eight or nine inches. Acted like robin, pulling up and listening for worms on lawn. Build of brown thrasher, somewhat. No yellow bill or orbit, was it a female? Yes, or young male bird. Bird very near. Saw it perfectly.

August 28th. Saw another just like description, but it seemed not so long a bird to me this time, more like our robin.

$$
\text { [ I 77] }
$$




\section{Bird Observations}

August 28th. Äschi. Wagtails. Saw about a dozen running about on the low roof of a chalet in a meadow, flying down to the meadow occasionally, but mostly sunning and preening themselves on the roof. One was evidently the pied, or the continental form, motacilla alba. In the one I saw at Grindelwald the breast seemed to have the black end in this shape at the bottom, not as in the picture.

The other wagtails were young pieds or the yellow, which? They answered to the description in Hudson "top of head, lore, nape, back and scapulars greenish olive, bright yellow streak over the eye, lower parts sulphur yellow," except that they did not seem as brightly colored as that, and they had a noticeable grey spot, rather large, on the breast, the coloring about the throat, sides of head, etc., was quite yel. lowish, outer tail feathers white. Wagtails do not carry their tails as high as our water thrushes, drag them more, but the motion is otherwise quite similar. Were these birds motacilla rayii or flava (European form of yellow), or young of lugubrir? Watched them a long time in excellent light.

August 29th. Saw three wagtails this [ 178 ] 


\section{Bird Observations}

a. m. very close too, all alike. Had grey upper parts, a pure grey, no olive, wings edged with white (each feather), and a white bar, tail with white outer feathers. No black on throat or breast except a large dark spot in the middle, forehead and sides of head and stripes over eye light, but not white, breast and belly without yellow, whitish.

August 29th. Spiez, Magpie. Came suddenly into sight in an apple tree. Splendid big fellow in his black and white. Chased a chaffinch (?) out of the tree.

August 29th. Spiez. Coal Titmouse. Followed the song, a sweet, clear "Hall-orree, hall-or-ree, hall-or-ree," then after while a change, on a different key, "whicher-ree," several times, the form reminding me of the Carolina wren, the tone of our chickadee's phoebe note, only not so plaintive, gayer, and a little thinner. He sat on a telegraph wire and sang over and over. I had heard the same notes in Grindelwald, but could not trace them. He looks very much like our chickadee, as does also-in less degree-the marsh titmouse.

August 29th. Spiez. Marsh Titmouse. Head and nape jet black, but no black on

$$
\text { [ I 79] }
$$




\section{Bird Observations}

throat. Saw two, one seemed to be keeping company with the coal tit.

August 29th. Spiez. Blue Titmouse. Just a glimpse of him, no such study as I've had of the great and the coal, but enough to be sure of his identity. Saw him well later.

August 28th-2gth. Spiez. Nightingale. Saw a bird dash out from shrubs near a garden wall, chase an insect and back several times, something like a flycatcher. Watched him again next day near an old barn in an orchard. Size and coloring seemed to answer exactly to the nightingale. He was very rufous on the tail and wings, light brown upper parts, and dull whitish breast, bill black, something like a bluebird's in shape (I should think), faint trace of light orbital ring, coloring on the whole something like our veery, only no spots on breast. What was it?

(Luscinia Philomela, in Paris Collection.)

A ugust 3oth. Had fine study of him, he was chasing flies over a cabbage patch (not pressing his breast against a thorn!). Bill was as above, legs and feet dark flesh color. He had a timid, thrush-like air, but would let me get quite near, he lifted his

$$
\text { [ } 180 \text { ] }
$$




\section{Bird Observations}

wings nervously once in awhile. He caught his food on the ground or made sallies after it in the air, and often lit on the top of a bean pole where I could see him to perfection. He could be nothing else but the nightingale, I feel sure. If I could only have heard his songs! (Proved to be above by collection in Paris.)

August 3oth. Spiez. Goldfinch. A pretty flock in a sunny meadow, all chirping together like our birds, but not quite so sweet a note. Charming birds, they were, but they did not stay long to be inspected. I saw a handsome male, though, with his red front. Chaffinches abound everywhere. Today, September 2 nd, one came right on to the porch where we were sitting. They are so tame.

September 2nd. St. Beatenberg. Wren. Scolded just like our wren and acted and looked very like him.

September 2nd. St. Beatenberg. Ruticilla tithys. Black Redstart. Had a good study of this bird, have had glimpses of him before in other places. He kept low, fed on the ground, flew in and out from stone piles and thickets. Size of bluebird, bill similar also, like a thrush bill. Upper parts dark bluish slate, lower the same,

$$
\text { [ } \mathrm{I} 8 \mathrm{I} \text { ] }
$$




\section{Bird Observations}

less bluish and not quite so dark, still not at all light, whole bird as dark as a junco, tail chestnut underneath, and with same color on the outer feathers (saw this plainly). Bird lifted his tail nervously quite often, and appeared shy, but came fairly near. Slight trace of light eye ring. Might have been a colaris, Alpine accentor, which is a little larger than modularis. Ruticilla tithys is this bird, some specimens very black, some just like above. ParisJardin des Plantes, verified bird notes. Wagtails were all albas that I saw, and though none had as little black on the breast as the birds I saw they must have been young ones, for no other motacillas were like them. No young in collection except two very young birds.

\section{[ 182$]$}




\section{(England)}

September I6th. Henley-on-Thames. Robin. So small compared with ours, and with such dainty, shy ways (but he isn't shy, really), a pretty fellow.

September 20th. Leamington. Abundant wherever I've been, and singing constantly even in dark damp weather. A tinkling song, stuttering a little at the outset, very varied, sweet - resembles slightly the shore lark's, but much more of a song. Sings from bushes close to you, or a coping, or from a housetop, as one did from a house opposite Shakespere's in Stratford.

September I6th. Henley-on-Thames. Heron, Dabchick, Moor Hen, Starling (a great flock), Rooks, Missal Thrush (a pair), Kingfisher, Pied Wagtail (Motacilla lugubris), several of these pointed out to me by Mr. Crisp-and not very good views of them. Starlings I saw well at Magdalene College, Oxford, afterwards, and rooks are everywhere, noticeable especially about the top of Guy's Tower, Warwick Castle.

September 2 Ist. Lichfield. Jackdaws in crowds about the spire of the cathedral. September 24th. Rowsley. Robins

$$
\text { [ } 183]
$$




\section{Bird Observations}

everywhere, and singing constantly-such a bubbling, rippling little song, all of a light and gentle character, but no two alike.

Rowsley. Song Thrush. Not a very good look at him, looked so yellowish on the sides of his breast. 
NOTES MADE FROM COLLECTION OF BIRDS IN ILLINOIS BUILDING AT THE WORLD'S FAIR

PIPITs. Fawn breast and belly, with a few grey spots, short white mark over eye, back slate, outer tail feathers white.

Cuckoos. Only difference is black billed species has ebony black bill, the yellow billed has lower madible and part of upper yellow.

SwALLOws. The rough-winged is the only dull grey swallow, and this is white on vent. Bank swallow, conspicuous white throat, grey breast and white belly, back dark greyish brown.

Tufted Titmouse resembles Cedar bird in shape, though colors are duller; has no black line through eye, back grey.

Bohemian Waxwing. Quite a little larger than Cedar bird. Breast of latter shades into pure white on belly and under tail, the Bohemian has belly same color as breast, cinnamon brown, and feathers under tail decidedly red. Bohemian here in winter.

SHRIKEs. Loggerhead seems much higher colored than Northern. Sharp jet

$$
\text { [ } 185 \text { ] }
$$




\section{Bird Observations}

black heavy mark through eye, throat pure white, breast almost so. Northern has breast with fine vermicular markings, which make it look much duller; black marks not so conspicuous. Loggerhead here in winter.

ORCHARD ORIOLE. One of the darkest colored birds we have. I can think of none except blackbirds, crows, and chewinks which are blacker.

Horned Lark. Prairie and Shore both here in winter. Latter has yellow stripes on head and throat yellow, where the former has white.

Nuthatches. White-breasted has only one broad black stripe on top of head, red breasted has several narrow ones.

Flycatchers. Crested: belly yellow, breast grey. Olive sided: large birds, white throat extending down in narrow line through middle of breast, breast sided with dark grey, quite a marked bird.

PhOEBE. White of throat extends half way around neck, showing at sides plainly; it does not extend so far in Pewee. The Pewees are darker and more slate colored than some of the Phoebes, some individuals of the latter being brownish and marked in stripes and dots.

$$
\text { [ I 86] }
$$




\section{Bird Observations}

Thrushes. It is very difficult to distinguish the Olive-backed from the Greycheeked. The throat of the Olive-backed is whiter, and breast spots rather darker and more clearly defined; it also has a marked ring of yellowish around eye, but the Grey-cheeked has this also, though not so distinctly. Breast spottings of both these thrushes are darker and more distinct than those of Wilson's Thrush (the Veery, or Tawny Thrush); the latter has rather faint tawny spots, which do not extend far down from the throat.

Vireos. The Warbling is the dullest colored and one of the smallest. It has a wavering white line over the eye which stops just in front of eye. The Red-eyed has a straight white line over the eye which extends to bill, giving a striped appearance to side of head; the Red-eyed is also decidedly green on the back and a much prettier and more elegant looking bird than the Warbling. Bell's Vireo is dull like the Warbling, but much smaller, the smallest of the family. Philadelphia vireo, a lovely bird, soft, delicate coloring, with faint wash of yellow on breast, back tinged with ashy red. Yellow-throated vireo, throat bright yellow (much yellower

$$
\text { [ } 187]
$$




\section{Bird Observations}

than the Yellow-bellied Flycatcher), distinct white marks on wing. The Whiteeyed vireo looks like a feeble edition of the Yellow-throated, washes of faint yellow on sides of breast and yellowish line over eye. Blue-headed vireo, very marked bird, slate blue head, line over and around eye white, throat pure white, shading to ashy on breast, a migrant.

Warblers. Tennessee as dull as the Warbling vireo, dullest of all except the Orange-crowned. The Tennessee has whiter throat than latter, and top of head is slate colored, of the Orange-crowned, reddish.

Sparrows. Field sparrow, dull and grey in color, no marks on breast, prevailing color dark. Leconte's, a little like Snowflake in color, light, warm tints prevailing. White-throated has plain grey breast below its white throat. Savanna resembles white-throated in its markings, having the striped appearance to the head, but the breast is heavily striped with black radiating from throat. Fox sparrow, very large, breast marked with large irregular reddish spots. White-crowned sparrow, equally large; no white on throat, breast plain ash.

$$
\text { [ } 188 \text { ] }
$$




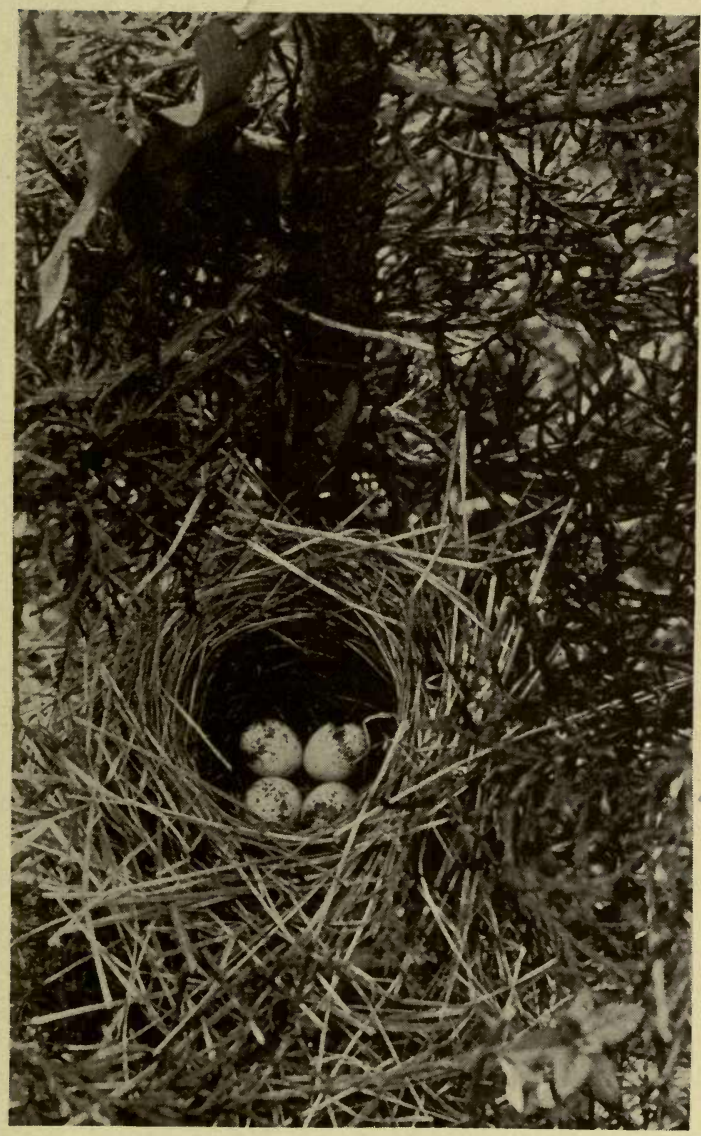

Nest of Fleld Sparrow 


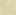




\section{BIRDS OBSERVED AT SAVAN- NAH, GEORGIA, FEBRUARY 20- MARCH 12, 1907}




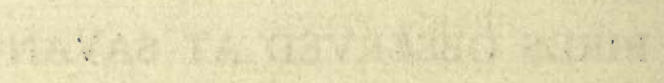

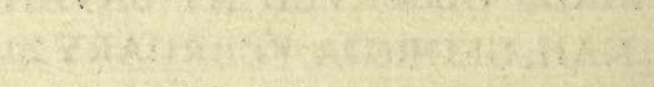

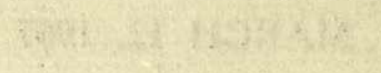




\section{BIRDS OBSERVED AT SAVANNAH, GEORGIA, FEBRUARY 20- MARCH I2, 1907}

SONG SPARROW, VESPER SPARROW, WHITE-THROATED SPARROW,

- MOCKING BIRD, CARDINAL, CAROLINA CHICKADEE, PURPLE FINCH, TURKEY BUZZARD, MEADOW LARK, TOWHEE, BLUE JAY, FISH CROW, ROBIN, CAROLINA WREN, TUFTED TITMOUSE, MYRTLE WARBLER, WAXWING, GOLDFINCH, BROWN THRASHER, KINGFISHER, FLICKER, RED-HEADED WOODPECKER, LOGGERHEAD SHRIKE, CHIPPING SPARROW, BLUEBIRD,

$$
\text { [ 19I ] }
$$




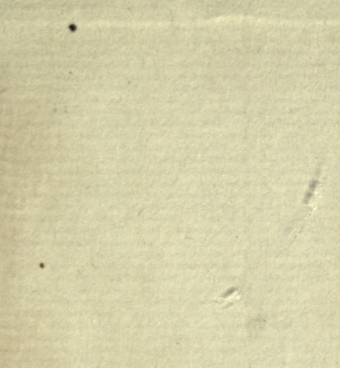

4 


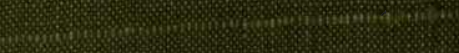

